\title{
ARE THE MEDITERRANEAN COUNTRIES WITH TOURISM PRICE INDICES IN THE PURCHASING POWER PARITY ZONE?
}

\author{
Jani Bekö ${ }^{1}$ \\ Darja Boršič ${ }^{2}$
}

DOI: https://doi.org/10.31410/tmt.2020.107

\begin{abstract}
This chapter provides a detailed analysis of the validity of PPP for a cluster of 15 Mediterranean countries. The research has four original contributions. First, it uses two price indicators: a consumer price index for all items and a consumer price index for hotels and restaurants including catering and accommodation services. Second, it tests the exchange rate theory regarding two numeraire currencies. Third, due to the cyclicality of the tourism sector the study examines the significance of PPP by considering the impact of the Great Recession. Fourth, in order to test the mean reversion hypothesis, it uses a comprehensive set of panel unit root tests. The authors provide ample estimates in favour of PPP proposition. The evidence of mean reversion of real exchange rates is stronger (1) with price indices for hotels and restaurants, (2) in cases when the calculations are performed for EUR rates, and (3) for the post-Great Recession period.
\end{abstract}

Keywords: Price competitiveness, Tourism sector, Panel unit root tests, Consumer price indices for hotels and restaurants.

\section{INTRODUCTION}

$\mathrm{O}^{\mathrm{n}}$ ne of the most important building blocks of open economy models is the theory of purchasing power parity (PPP). It is also one of the most intensively evaluated topics in empirical economics and the nature of the relationship between exchange rates and consumer prices are often subject of fierce theoretical discussions. The rigorous version of the PPP anticipates that the ratio of price levels of countries determines their exchange rate. In general, the absolute PPP therefore predicts that the price levels of observed countries should be equal when calculated in terms of the same currency. The relative PPP on the other side implies that shifts in the exchange rates are equal to the changes in the national price levels. Following this notion, changes in relative national price levels can serve as a fairly accurate approximation of exchange rate movements. The key driving force behind the PPP theory is international goods market arbitrage - the process of competition which eliminates significant price differences among markets. Because the arbitrage on goods markets takes time, the deviation of exchange rates from the PPP predicted levels can be substantial in the short run, although in the long run the convergence to the PPP determined levels is empirically documented. According to the latest estimates by Rabe and Waddle (2020), for example, for the past five decades, there is evidence of an increase in the speed of adjustment of international prices toward PPP levels. A study of commodity price data over seven centuries by Froot et al. (2019), however, reveals that goods markets can be frequently segregated and thus the process of arbitrage defective.

University of Maribor, Faculty of Economics and Business, Razlagova 14, 2000 Maribor, Slovenia University of Maribor, Faculty of Economics and Business, Razlagova 14, 2000 Maribor, Slovenia 
There are several possible factors responsible for the violation of PPP. Among others, Taylor and Taylor (2004) stress the importance of high transport costs, taxes, tariffs and nontariff barriers, which can block an effective price arbitrage. The presence of differentiated, non-substitutable goods and the inclusion of non-tradable goods into price indices further complicate the PPP standard. The slow speed of adjustment of real exchange rates toward PPP equilibrium rates has been frequently attributed to a nonlinear adjustment of exchange rates. Taylor (2006) elaborates a diverse set of factors causing nonlinear dynamics of exchange rates; for example, market expectations about the appropriate exchange rate adjustment may trigger heterogeneous interactions of traders, and under fundamental exchange rate misalignments monetary policy actions can spur important coordination effects among the main traders. In addition to studies that examine the short-run factors causing a departure from equilibrium exchange rates and to those which investigate the process of mean reversion in itself, the possible variability of the long-run equilibrium real exchange rate remains a further research option in the PPP puzzle. Taylor and Taylor (2004), for example, examine scenarios, where shifts in the long-run equilibrium real exchange rate can be caused by productivity shocks, due to profound institutional and structural transformation of economies or due to the shocks in economic policy.

This study aims to extend the empirical evidence about PPP proposition by focusing on a sample of 15 Mediterranean countries. These countries have some interesting characteristics. First, they all belong to the group of open economies, strongly integrated in the global production and trade flows. The group's lowest trade to GDP ratios are in Egypt (48\%), Algeria (52\%) and Israel (58\%), whereas in most open Mediterranean economies the share of exports and imports of goods and services in GDP amounts to $261 \%$ in Malta, $160 \%$ in Slovenia and $143 \%$ in Cyprus (The World Bank, 2020). Second, the aforementioned countries are well recognized on the world tourism market. The tourism sector can represent a significant portion of the countries' economic power as well as it can be an important driver of international trade in services. The relative strength of the country's tourism sector is determined by three factors: its geographical location, the development of infrastructure and the established price competitiveness. The tourism sector with its many growth enhancing effects and spillovers on productivity, employment, income and on the balance of payments is an important vehicle for economic development and prosperity in the Mediterranean countries. Consequently, the contribution of the travel and tourism industry to GDP of these countries is significant. At the bottom of the ladder are Israel $(6 \%)$, Algeria (7\%) and France (10\%), whereas in Albania (27\%), Croatia (25\%), Cyprus (23\%) and Greece (21\%) the travel and tourism sector adds the largest chunk to country's GDP (Knoema, 2020). Third, the Mediterranean countries participate in economic integrations with various levels of complexity. Some of them nurture pure trade and commercial links with the European Union; Croatia, for example, is a member of the European Union but retains its monetary sovereignty, while some countries in our sample embraced even higher level of economic integration by officially adopting the single European currency. And finally, the Mediterranean group consists of countries with indicative institutional disparities as well as with pronounced differences in their levels of economic development.

Our research has four original contributions. First, it uses two price indicators: consumer price index for all items and consumer price index for hotels and restaurants including catering and accommodation services. Second, it tests the PPP proposition regarding two numeraire currencies (EUR, USD). Third, due to the cyclicality of the tourism sector and its influence on countries' economy the present study examines the validity of PPP by considering the impact of the Great Recession. Therefore, after testing the PPP theory for the whole period (February 
1998-February 2020), the analysis is divided into the pre-crisis period (up to December 2007) and the post-crisis period (from July 2009 on). Fourth, in order to test the mean reversion hypothesis of real exchange rates we employ a comprehensive set of panel unit root tests: Im, Pesaran and Shin test, ADF-Fisher test, PP-Fisher test, Levin, Lin and Chu test, and Breitung test.

The study is divided into the following seven sections. After the introduction, the most relevant PPP studies for the targeted group of Mediterranean countries are reviewed in the second section. Besides a concise description of the PPP theory, the third section also presents the used econometric methodology. The description of the relevant data set is given in the fourth section, whereas the empirical results and possible extensions of the current research are discussed in separate sections. The main conclusions of the study are summarized in the final section.

\section{OVERVIEW OF LITERATURE}

A review of the recent empirical literature on PPP shows that analysts try to apply different research strategies for the verification of this exchange rate theory. Adoption of improved, alternative methodological approaches, development of new estimation techniques, testing of larger data sets, examining long-span data on exchange rates and prices, and extending the analysis on a large number of countries are all feasible options in search for the PPP. Despite comprehensive research work, the evidence on PPP remains inconclusive (Taylor, 2006). The strengthening globalization, increasing competition from developing countries and their consequent economic expansion, as well as the growing trade with services motivated the experts to evaluate this exchange rate concept not just for major developed countries but also for various groups of emerging economies. In this section, we briefly present those relevant PPP studies which either directly cover only the group of Mediterranean countries or at least include a significant number of these countries in the research procedure.

In one of the early attempts, without an explicit test of PPP, Laureti (2001) provided statistical evidence of the correlation between changes in the exchange rates (domestic currency/ecu) and inflation in 12 Mediterranean countries. The results imply that with the growing integration of Mediterranean economies with the European Union there is a circumstantial evidence of PPP-type adjustment of exchange rates. Camarero et al. (2006) scrutinized the real effective exchange rates of 10 Mediterranean countries with the European Union from 1979 to 2002. Only after allowing for structural breaks and nonlinearities in the specification, the PPP could be confirmed for 5 Mediterranean economies.

The exchange rate series of Mediterranean countries are frequently combined with data of other countries to examine the equilibrium parity conditions on a larger sample of countries. Bahmani-Oskooee and Hegerty (2010), for example, tested 123 countries' bilateral exchange rates against the US dollar. Although the nominal exchange rates and the relative price levels were found to be cointegrated for the majority of countries in the sample, only in few cases are the restrictions on coefficients for PPP achieved. Results from cointegration analysis coupled with testing of symmetry and proportionality conditions in Arize et al. (2015) offer substantially more support for the long-run relationship between nominal exchange rates, domestic and US price indices in 116 economies. Conclusive evidence about the empirical fulfillment of the PPP theory is additionally presented in Ramajo and Ferré (2010), and Bahmani-Oskooee et al. (2014). Both studies operate with data of members of the Organisation for Economic Co-operation and Development and adopt a battery of empirical techniques ranging from individual and 
panel unit root tests, panel KSS unit root tests with a Fourier function to individual and panel cointegration tests. Not all studies with large-scale samples of countries have gained outcomes favourable to PPP. Su et al. (2014) examined monthly data on real effective exchange rates for 61 (including the Mediterranean) countries from 1994 to 2012. After considering heteroscedasticity and nonlinearity, the authors have proved that the real effective exchange rates for the majority of economies under observation are nonstationary.

Thorough investigation of the PPP dictum for the Middle East and North African countries is reported by Bahmani-Oskooee and Kandil (2007), and Kula et al. (2011). In Bahmani-Oskooee and Kandil (2007), the real effective exchange rate series for 14 the Middle East and North African economies are evaluated with the KPSS test and the parity conditions are accepted in around half of the cases observed. The authors' estimations also show that in many of these countries nominal depreciation of exchange rates spills into real depreciation in the short-run as well as in the long-run. On the other hand, Kula et al. (2011) apply the Lagrange Multiplier unit root test for official and black market exchange rates of 13 the Middle East and North African countries. After incorporating structural breaks in the data series from 1970 to 1998 , the presence of mean reversion is established in 4 official exchange rates and in 5 black market exchange rates.

Koedijk et al. (2004) tested the characteristics of exchange rates of 10 euro area economies for the period 1973-2003 and found evidence in favour of PPP for the full panel of real exchange rates. For the period 1996-1999 Lopez and Papell (2007) can reject the unit root hypothesis within the euro area and between the euro area and other industries as well as other European Union countries. They report about stronger PPP links within the euro group than between the euro area and other European and Mediterranean countries. Giannellis and Papadopoulos (2010) also provided evidence that in 1980-2006 the majority of tested real exchange rates of 14 Eurozone countries followed an adjustment path consistent with PPP. Similar findings are reported in Emirmahmutoglu and Omay (2014). Using a sequential panel selection method in ESTAR tests for a sample of period 1988-2013, the authors proved the existence of nonlinear stationarity of quarterly real exchange rates for 8 out of 15 European Union members against the US dollar.

In Zhou and Kutan (2011) the results of stationarity of real exchange rates for European Union countries are sensitive to sample period changes and the readjustment of real exchange rates often followed a nonlinear path. The PPP hypothesis could not be corroborated for original members of the Eurozone neither between 1973-2009 nor in the subperiod after the official formation of the Eurozone area in the paper written by Christidou and Panagiotidis (2010). Very much in line with these results are also the findings of Wu and Lin (2011), and Huang and Yang (2015). The quoted authors verified the mean-reversion of real exchange rates against the US dollar before the adoption of the euro but failed to reject the hypothesis of a unit root after the introduction of the single European currency.

Among studies that focus exclusively on new members of the European Union and are relevant for our current research, we highlight the work of Koukouritakis (2009), Boršič et al. (2012) and Bekő et al. (2012). Koukouritakis (2009) analysed the theory of PPP determined exchange rates for twelve new European Union members using Johansen cointegration methodology, but he was able to confirm the long-run PPP concerning The Eurozone only for Bulgaria, Cyprus, Romania and Slovenia. From the sample of twelve new European Union countries, Boršič et al. 
(2012) rejected the unit root hypothesis for five countries based on the SURADF test, whereas Bekő et al. (2012) utilizing nonlinear unit root tests based on the ESTAR model locate nine cases of real exchange rates vis-à-vis the euro with stationary properties.

Recently, Papell and Prodan (2020) introduced a methodology that is robust to small departures from the standard unit root model on the applicable data from 1870 to 2013 for 16 developed economies. Two main findings can be derived from the study that examines long-run co-variability between nominal exchange rate changes and differences in inflation rates. First, according to the results, the long-run PPP in reference to the US dollar cannot be rejected for 9 countries in the surveyed sample. And second, the PPP-type mechanism is stronger in countries with high inflation dynamics and high depreciation rates.

\section{THE THEORY OF PPP AND ECONOMETRIC METHODOLOGY}

According to Froot and Rogoff (1995) the PPP can be formally stated as:

$$
e_{t}=\alpha_{0}+\alpha_{1} p_{t}+\alpha_{2} p_{t}^{*}+\xi_{t}
$$

where $e_{t}$ denotes the logarithm of nominal exchange rates, $p_{t}$ stands for the logarithm of domestic price index and $\mathrm{p}_{\mathrm{t}}{ }^{*}$ for the logarithm of foreign price index. The error term $\xi_{\mathrm{t}}$ represents deviations from PPP. The nominal exchange rates are defined as the price of foreign currency in the units of domestic currency.

This section assesses the characteristics of real exchange rates taking into account the strict version of PPP in Equation 1, where $\alpha_{0}=0, \alpha_{1}=1$ and $\alpha_{2}=-1$. The changes in relative prices should be eliminated by the changes in nominal exchange rates. Thus, the real exchange rates series are expected to be stationary, with no unit root, which indicates that the real exchange rates are constant over the long-run (Parikh \& Wakerley, 2000).

Panel unit root procedures are tested in order to find evidence for validity of PPP. As described in Bekő and Boršič (2018) the model applies the following AR(1) process for panel data:

$$
y_{i, t}=\rho_{i} y_{i, t-1}+X_{i, t} \delta_{i}+\varepsilon_{i, t}
$$

where $\mathrm{i}$ denotes $\mathrm{N}$ cross-section units observed over periods $\mathrm{t}=1,2, \ldots, \mathrm{T}_{\mathrm{i}}$, $\mathrm{X}_{\mathrm{i}, \mathrm{t}}$ presents exogenous variables in the model (any fixed effects or individual trends), $\rho_{\mathrm{i}}$ stands for autoregressive coefficients, while $\varepsilon_{\mathrm{i}, \mathrm{t}}$ symbolizes errors, which are assumed as mutually independent idiosyncratic disturbance. Panel of $y_{i}$ is weakly stationary if the absolute value of $\rho_{i}$ is less than one. On the other hand, $y_{i}$ contains a unit root if the absolute value of $\rho_{i}$ is 1 . There are two assumptions about the $\rho_{\mathrm{i}}$ in panel unit root tests in our analysis. Im et al. (2003), Fisher ADF and Fisher PP tests' (Maddala \& Wu, 1999; Choi, 2001) procedures assume individual unit root processes, meaning that $\rho_{\mathrm{i}}$ vary across cross-sections. Levin et al. (2002) and Breitung (2000) approaches deal with common unit root processes, where there are common autoregressive coefficients across cross-sections $\left(\rho_{i}=\rho\right)$ for all i. According to Boršič and Bekő (2018) the preceding subsections summarize the main specific attributes of individual panel unit tests used in this study. 


\subsection{Main attributes of Im, Pesaran and Shin test}

Im et al. (2003) estimate individual ADF regression for each cross-section taking into account individual unit root processes:

$$
\Delta y_{i, t}=\alpha y_{i, t-1}+\sum_{j=1}^{p_{i}} \beta_{i, j} \Delta y_{i, t-j}+X_{i, t}^{\prime} \delta+\varepsilon_{i, t}
$$

with the null hypothesis of

$$
H_{0}: \alpha_{i}=0 \text {, for all } i
$$

and the alternative hypothesis determined by:

$$
H_{1}:\left\{\begin{array}{lll}
\alpha_{i}=0 & \text { for } \quad \mathrm{i}=1,2, \ldots, \mathrm{N}_{1} \\
\alpha_{i}<0 & \text { for } \quad \mathrm{i}=\mathrm{N}_{1}+1, \ldots, \mathrm{N}
\end{array}\right.
$$

In Equation $6 \bar{t}$ stands for the average of the t-statistics for $\alpha_{\mathrm{i}}$ from individual ADF regressions:

$$
\bar{t}=\frac{1}{N} \sum_{i=1}^{N} t_{i}
$$

Im et al. (2003) provide procedure to standardize the $\bar{t}$-statistic and empirically demonstrate that the new statistic $\mathrm{W}$ is asymptotically normally distributed.

\subsection{Main attributes of Fisher ADF and Fisher PP tests}

Based on the results of Fischer (1932), Maddala and Wu (1999) and Choi (2001) developed tests that integrate the individual $p$-values. In Equation $7 \pi_{\mathrm{i}}$ presents the $p$-value from individual unit root test for cross-section i. Taking into account the findings of Hurlin (2010) the corresponding p-values are uniform $[0,1]$ variables. Maddala and $\mathrm{Wu}(1999)$ determine their $\chi^{2}$ test statistic:

$$
\chi^{2}=-2 \sum_{i=1}^{N} \log \left(\pi_{i}\right)
$$

and show that it follows an asymptotic $\chi^{2}$-distribution with $2 \mathrm{~N}$ degrees of freedom. Choi (2001) develops a similar Z statistic:

$$
Z=-\frac{\sum_{i=1}^{N} \log \left(\pi_{i}\right)+N}{\sqrt{N}}
$$

In both set of the tests the null hypothesis is the same as in Equation 4, while the alternative hypotheses are the same as in Equation 5. Under the null hypothesis, Z-statistic is normally distributed.

\subsection{Main attributes of Levin, Lin and Chu test, and Breitung test}

Levin, Lin and Chu test (Levin et al. 2002) utilizes the ADF regression defined as:

$$
\Delta y_{i, t}=\alpha y_{i, t-1}+\sum_{j=1}^{p_{i}} \beta_{i, j} \Delta y_{i, t-j}+X_{i, t}^{\prime} \delta+\varepsilon_{i, t}
$$


where $\alpha$ is assumed to be common and defined as $\alpha=\rho-1, p_{\mathrm{i}}$ stands for the lag order for different terms and it varies across cross-sections. The null hypothesis is stated as $\mathrm{H}_{0}: \alpha=0$ and indicates a unit root. The alternative hypothesis is defined as $\mathrm{H}_{1}: \alpha<0$ and it indicates stationarity. In Levin et al. (2002) approach auxiliary regressions of $\Delta \mathrm{y}_{\mathrm{i}, \mathrm{t}}$ and $\mathrm{y}_{\mathrm{i}, \mathrm{t}}$ on lagged terms $\Delta \mathrm{y}_{\mathrm{i}, \mathrm{t}-\mathrm{j}}$ and on exogenous variables $\mathrm{X}_{\mathrm{it}}$ are estimated. The estimates of $\alpha$ are developed from the pooled equation:

$$
\Delta \widetilde{y}_{i, t}=\alpha \widetilde{y}_{i, t-1}+\eta_{i, t}
$$

where standardized proxies (denoted by $\sim$ ) for $\Delta \mathrm{y}_{\mathrm{i}, \mathrm{t}}$ and $\mathrm{y}_{\mathrm{i}, \mathrm{t}}$ are used with autocorrelations and deterministic components removed. Since the standard t-statistic for testing the hypothesis $\hat{\alpha}=0$ diverges to negative infinity, Levin et al. (2002) developed the modified t statistics $\left(\mathrm{t}^{*}\right)$ :

$$
t^{*}=\frac{1}{\sigma^{*}}\left(t-N T \cdot \hat{S}_{N} \hat{\sigma}^{-2} \hat{\sigma}_{\alpha} \mu^{*}\right)
$$

where $\mu^{*}$ and $\sigma^{*}$ denote the adjustment terms for the mean and standard deviation as calculated by Levin et al. (2002), $\hat{\sigma}_{\alpha}$ presents the standard error of $\hat{\alpha}$, and $\hat{\sigma}^{2}$ stands for the estimated variance of the error term from equation (10). $\hat{S}_{N}$ is the average of individual ratios of long-run to short-run standard deviations and it is estimated with kernel-based techniques. The authors prove that $t^{*}$ is asymptotically normally distributed.

The Breitung test is similar to Lin, Levin and Chu test as it is based on the same ADF specification stated in Equation 9. However, it calculates auxiliary regressions of $\Delta \mathrm{y}_{\mathrm{i}, \mathrm{t}}$ and $\mathrm{y}_{\mathrm{i}, \mathrm{t}}$ on lagged terms $\Delta \mathrm{y}_{\mathrm{i}, \mathrm{t-j}}$ only, while proxies are transformed and detrended $\left(\Delta y_{i t}{ }^{*}\right)$. In order to estimate the persistence parameter $\alpha$ panel proxy equation is applied:

$$
\Delta y_{i t} *=\alpha y_{i t-1} *+v_{i t}
$$

Breitung (2000) proves that the estimate of the persistence parameter $\alpha$ is asymptotically normally distributed under the null hypothesis.

\section{PRESENTATION OF APPLIED DATA}

The preceding empirical investigation of PPP validity is based on monthly data covering the period from February 1998 to February 2020 for 15 Mediterranean economies, including Albania, Algeria, Croatia, Cyprus, Egypt, France, Greece, Italy, Malta, Morocco, Slovenia, Spain, Israel, Tunisia and Turkey.

The consumer price indices (CPI) and the monthly averages of nominal exchange rates with reference currencies of Euro (EUR) and US dollar (USD) were gathered from International Monetary Fund (2020). In order to test the validity of PPP in the tourism sector, we assembled the CPI for hotels and restaurants (CPI C11) from Eurostat (2020) for Croatia, Cyprus, France, Greece, Italy, Malta, Slovenia, Spain, Turkey, while CPI C11 data for Israel was taken from OECD (2020). Thus, due to the limited availability of data about CPI for tourism services the validity of PPP in tourism sector was scrutinized for 10 countries out of the whole dataset of 15 above stated economies. CPI C11 data for the USA is available at Eurostat since January 2002. In pursuance of applying the longest possible data span, we prolonged the Eurostat data series for USA CPI C11 by CPI data from the U.S. Bureau of Labor Statistics (2020). Thus, we calculated the proxy for CPI C11 data from February 1998 to December 2001 by taking the arithmetic average of data 
series CPI for "full service meals and snacks" (BLS series code: CUUR0000SEFV01), and data series CPI for "other lodging away from home including hotels and motels" (BLS series code: CUUR0000SEHB02).
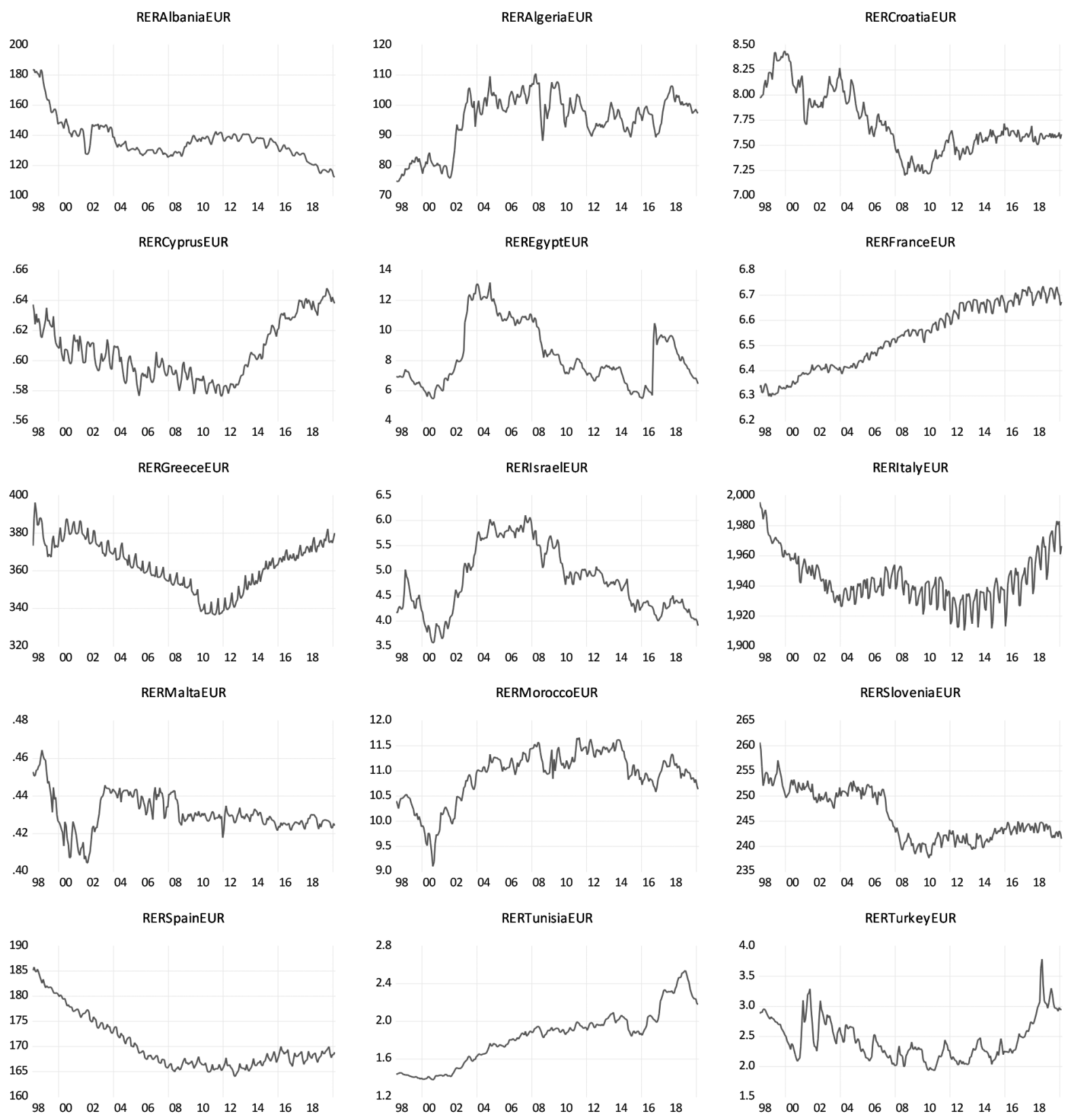

Figure 1. Real exchange rates among currencies of individual Mediterranean countries and EUR using CPI (All items) as deflator

Source: Authors calculation

The first step in testing the strict version of PPP requires the calculation of real exchange rates:

$$
R E R=N E R \frac{P^{*}}{P}
$$

where RER stands for real exchange rate, NER is abbreviation for nominal exchange rate defined as a price of foreign currency in units of domestic currency, $\mathrm{P}^{*}$ is foreign price index and $\mathrm{P}$ is domestic price index. There are four sets of real exchange rates used in the empirical analysis. 
Namely, the real exchange rates are calculated by two reference currencies (EUR and USD) and by using two different price deflators: CPI for the whole economy (CPI All items) and CPI for tourism services (CPI C11 Hotels and restaurants).
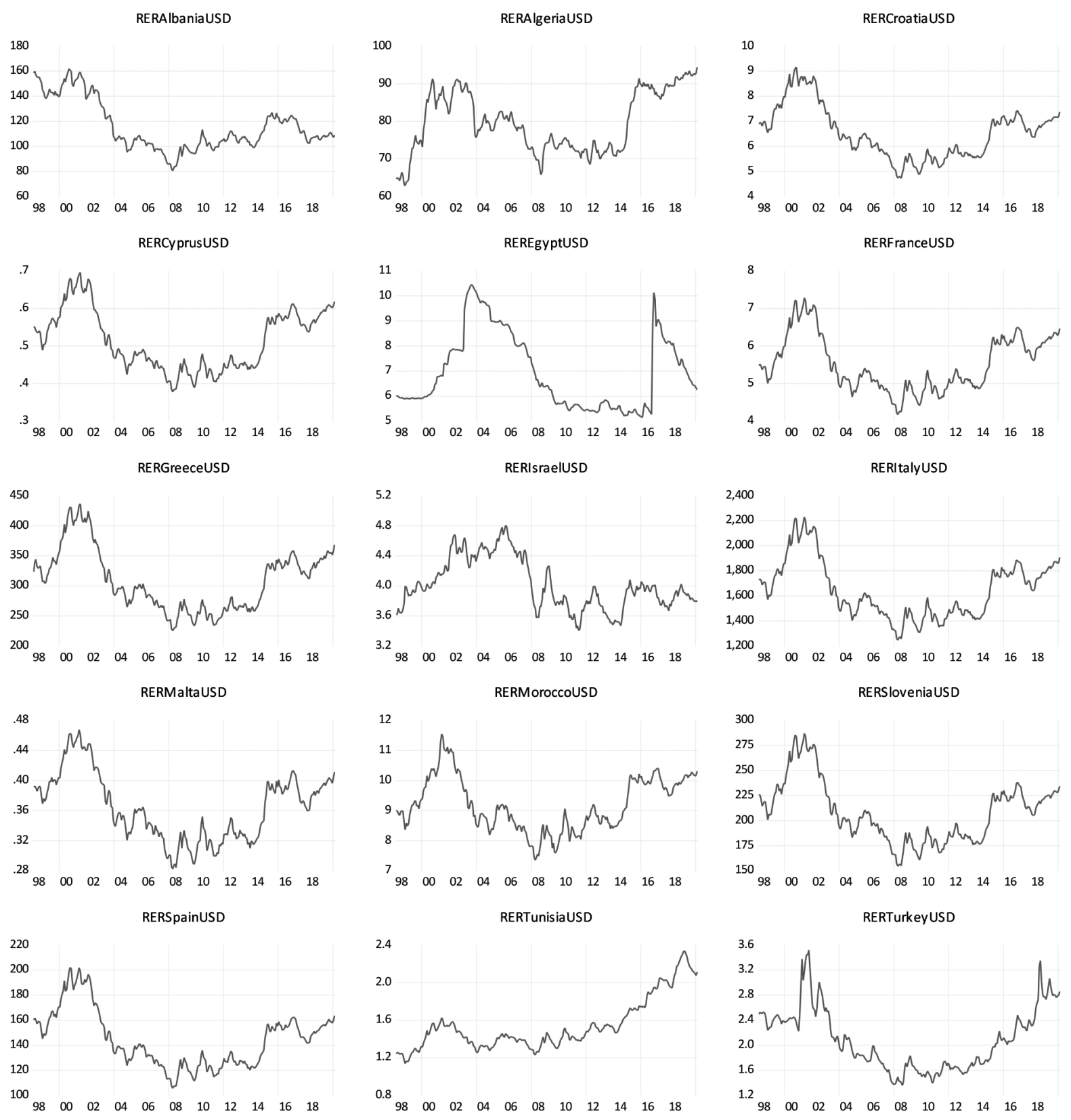

Figure 2. Real exchange rates among currencies of individual Mediterranean countries and USD using CPI (All items) as deflator

Source: Authors calculation

Data on the level of real exchange rates calculated by CPI (All items) are presented in Figures 1 and 2, while data on the level of real exchange rates based on CPI for tourism services are displayed in Figures 3 and 4. On the other hand, the empirical analysis is conducted by using logarithmic values of individual real exchange rates.

Figure 1 presents real exchange rates of national currencies with respect to EUR taking into account the general CPI indices (All items). In the first observed year, from February 1998 to 
December 1998, ECU is used as the reference currency. Since the introduction of euro in January 1999 the official fixed euro conversion rates are taken into account for France, Greece, Italy and Spain, as well as for Slovenia since 2007 and for Malta and Cyprus since 2008. As stated in equation 13, the real exchange rates in euro area members differ in line with fluctuations of relative prices. Thus, despite the common currency, the real exchange rates are defined by relative prices in regard to euro area. Taking into account the whole observed period, Figure 1 shows real appreciation for Albanian lek and EUR in Malta, Slovenia and Spain. On the other hand, real depreciation is recorded for EUR in France, Algerian dinar and Tunisian dinar. In Croatia, Cyprus, Greece, Italy and Turkey real appreciation in the pre-crisis period was followed by real depreciation. The opposite development of real exchange rates is recorded in Egypt, Israel and Morocco, where real depreciation is followed by real appreciation in recent years.
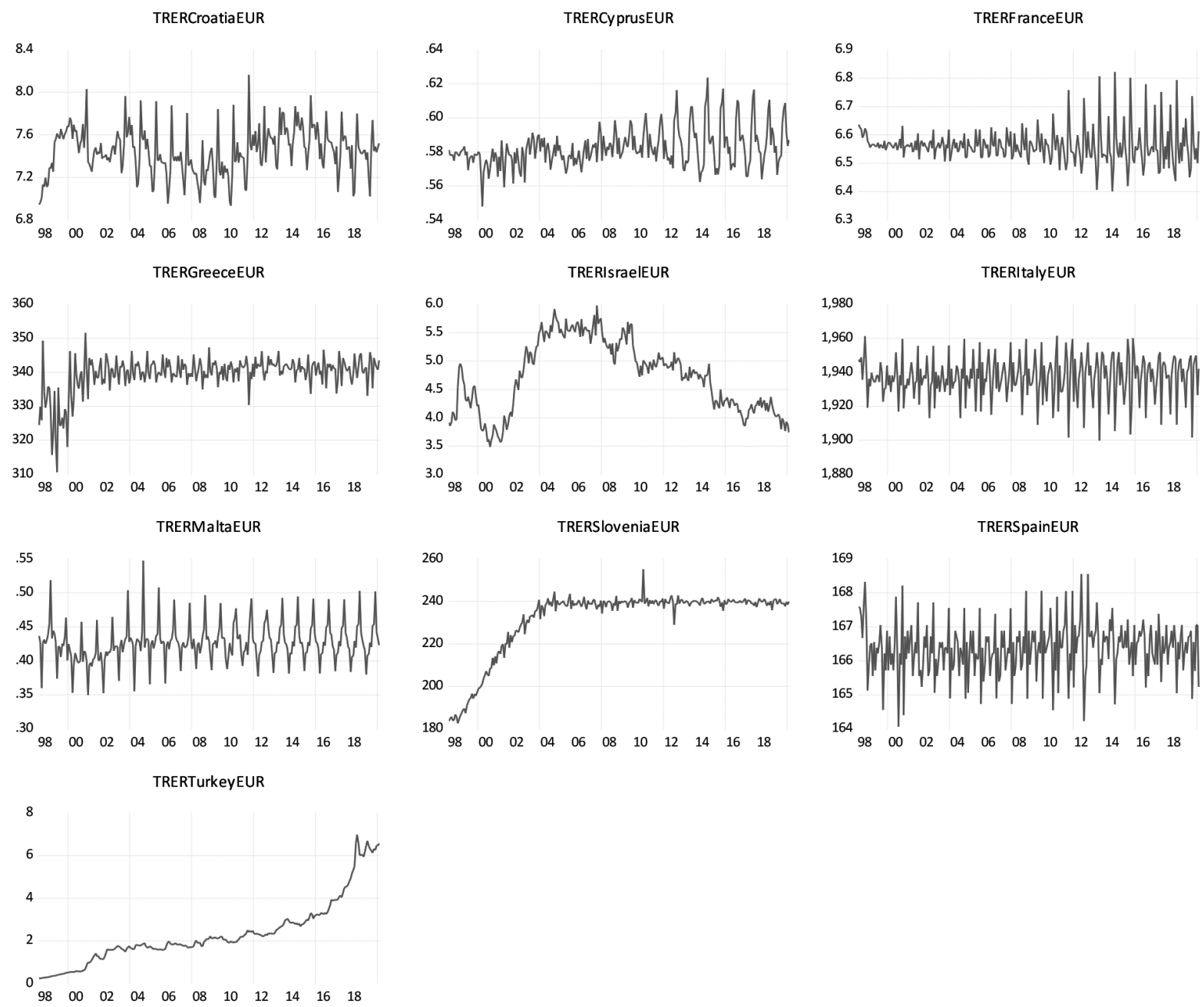

Figure 3. Real exchange rates among currencies of individual Mediterranean countries and EUR using CPI (Hotels and restaurants) as deflator

Source: Authors calculation

The real exchange rates of national currencies regarding USD, taking into account the general CPI (All items), are exhibited in Figure 2. Almost all national currencies (except Albanian lek, Egyptian pound and Turkish lira) recorded a real depreciation at the beginning of the first three to four years, which was followed by a sharp real appreciation in 2004. A relatively stable period with some short run fluctuations ended in 2014 when real depreciation is recorded. 
Figure 3 and 4 exhibit real exchange rates regarding EUR and USD, respectively, taking into account the CPI for hotels and restaurants. In this case, most of the EUR real exchange rates (Figure 3) are relatively stable in the long run with short run fluctuations around the long-run average rates. As for Israeli pound there is real depreciation recorded in the first part of the observed period followed by real appreciation in the post-crisis period. The real exchange rate of EUR in Slovenia also exhibit stable long run values since its introduction, while Slovenian tolar has exhibited real depreciation before entering the ERMII mechanism in 2004. On the other hand, Turkish lira features real depreciation over the whole observed period, which has gathered momentum in the last 4 years.
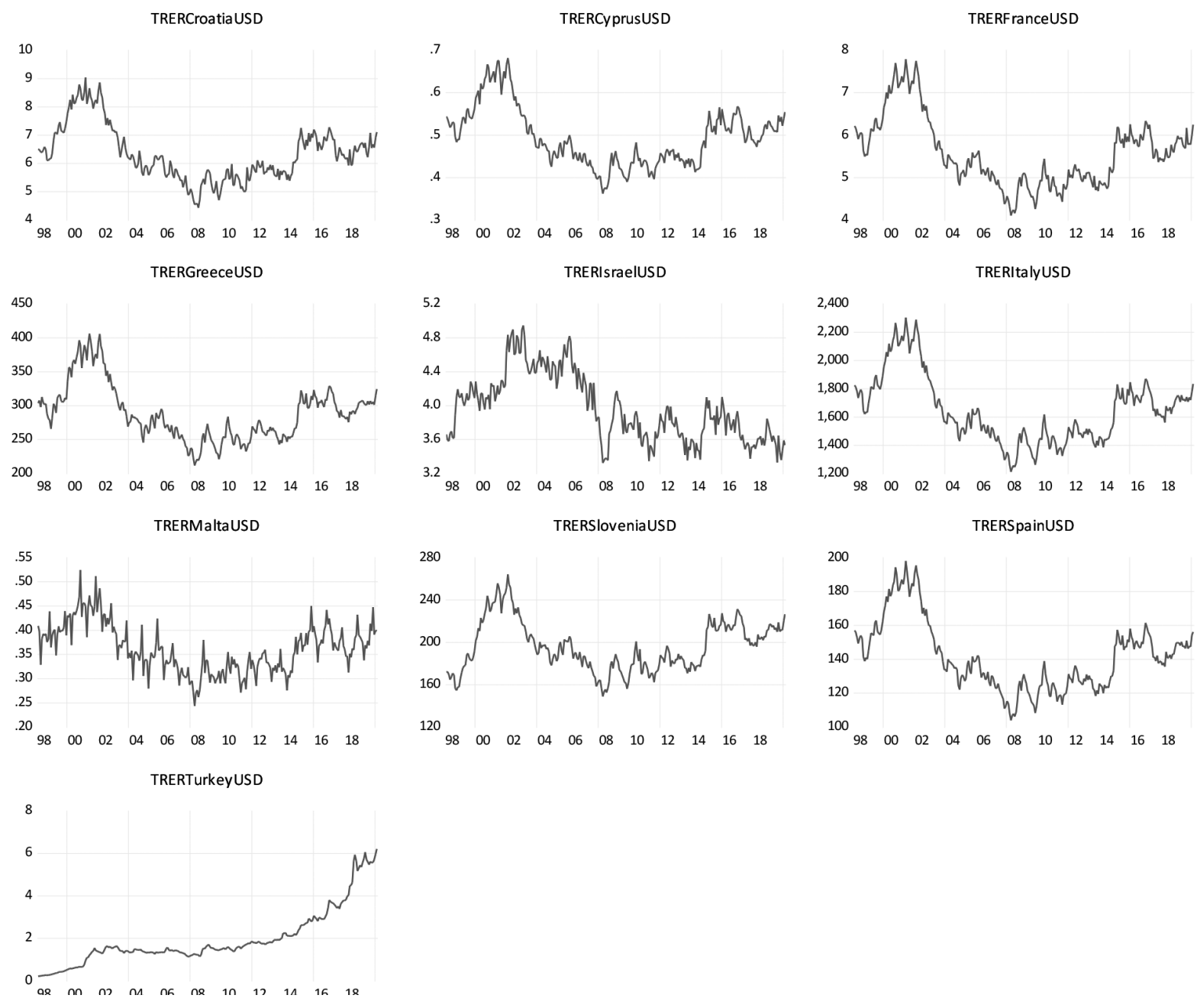

Figure 4. Real exchange rates among currencies of individual Mediterranean countries and USD using CPI (Hotels and restaurants) as deflator

Source: Authors calculation

Real exchange rates, concerning USD taking into account the deflator of CPI for hotels and restaurants in Figure 4, show very similar developments to real exchange rates of USD taking into account the general CPI for all items presented in Figure 2, except for Turkish lira, which exhibits real depreciation over the whole observed period, and its fluctuation is similar to the EUR real exchange rates deflated by CPI for hotels and restaurants. 


\section{EMPIRICAL RESULTS}

For both deflators, the empirical study was performed in three parts. First, we considered the whole observed period (February 1998-February 2020). Second, we took into account the pre-economic crisis period ranging from February 1998 to December 2007. And third, we examined the post-economic crisis period covering data from July 2009 to February 2020. In order to determine the sub-periods, the NBER (2012) methodology for defining the US business cycles was adapted. Thus, each table in the preceding section presents the results of individual panel unit root tests for all three periods. First, we examine the PPP validity by taking into account the general CPI deflator followed by the results when the CPI for tourism services was applied.

\subsection{Results based on general consumer price indices}

All of the conducted panel unit root tests examine the same null hypothesis that there is a unit root. Thus, results rejecting the null hypothesis provide evidence in favour of PPP for which the series and/or panel in question should be stationary. Table 1 presents results of Im, Pesaran and Shin test being conducted by three different information criteria to determine the lags (Schwarz, Akaike and Hannan-Quinn information criteria). For each case we took into account the individual effects as well as individual linear trends. Bearing in mind the $10 \%$ significance level, the results show that the PPP could be confirmed for the EUR reference rates in the whole observed period when only individual effects are allowed for.

Table 1. Results of Im, Pesaran and Shin test, deflator: CPI (All items)

\begin{tabular}{|c|c|c|c|c|c|c|c|}
\hline \multirow{3}{*}{ 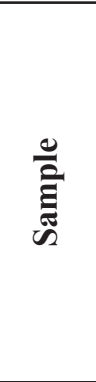 } & \multirow{3}{*}{ 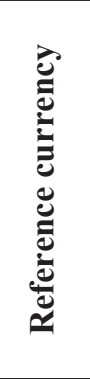 } & \multicolumn{2}{|c|}{$\begin{array}{c}\text { Schwarz information } \\
\text { criterion }\end{array}$} & \multicolumn{2}{|c|}{$\begin{array}{c}\text { Akaike information } \\
\text { criterion }\end{array}$} & \multicolumn{2}{|c|}{$\begin{array}{c}\text { Hannan-Quinn } \\
\text { information criterion }\end{array}$} \\
\hline & & $\begin{array}{l}\text { Individual } \\
\text { effects }\end{array}$ & $\begin{array}{c}\text { Individual } \\
\text { effects and } \\
\text { individual } \\
\text { linear trends }\end{array}$ & $\begin{array}{c}\text { Individual } \\
\text { effects }\end{array}$ & $\begin{array}{c}\text { Individual } \\
\text { effects and } \\
\text { individual } \\
\text { linear trends }\end{array}$ & $\begin{array}{c}\text { Individual } \\
\text { effects }\end{array}$ & $\begin{array}{l}\text { Individual } \\
\text { effects and } \\
\text { individual } \\
\text { linear trends }\end{array}$ \\
\hline & & $\begin{array}{c}\text { W-stat } \\
\text { (p-value) } \\
\text { [no. of lags] }\end{array}$ & $\begin{array}{c}\text { W-stat } \\
\text { (p-value) } \\
{[\text { no. of lags] }}\end{array}$ & $\begin{array}{c}\text { W-stat } \\
\text { (p-value) } \\
\text { [no. of lags] }\end{array}$ & $\begin{array}{c}\text { W-stat } \\
\text { (p-value) } \\
{[\text { no. of lags] }}\end{array}$ & $\begin{array}{c}\text { W-stat } \\
\text { (p-value) } \\
\text { [no. of lags] }\end{array}$ & $\begin{array}{c}\text { W-stat } \\
\text { (p-value) } \\
\text { [no. of lags] }\end{array}$ \\
\hline \multirow{2}{*}{ 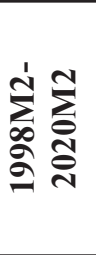 } & EUR & $\begin{array}{c}-1.67343 \\
(0.0471) \\
{[12]}\end{array}$ & $\begin{array}{c}1.43217 \\
(0.9240) \\
{[13]}\end{array}$ & $\begin{array}{c}-1.71768 \\
(0.0429) \\
{[12]}\end{array}$ & $\begin{array}{c}1.43777 \\
(0.9248) \\
{[13]}\end{array}$ & $\begin{array}{c}-1.36632 \\
(0.0859) \\
{[13]}\end{array}$ & $\begin{array}{c}1.66243 \\
(0.9518) \\
{[13]}\end{array}$ \\
\hline & USD & $\begin{array}{c}-0.42466 \\
(0.3355) \\
{[2]}\end{array}$ & $\begin{array}{c}2.63574 \\
(0.9958) \\
{[2]}\end{array}$ & $\begin{array}{c}-0.29975 \\
(0.3822) \\
{[14]}\end{array}$ & $\begin{array}{c}2.77782 \\
(0.9973) \\
{[14]}\end{array}$ & $\begin{array}{c}-0.36739 \\
(0.3567) \\
{[2]}\end{array}$ & $\begin{array}{c}2.71066 \\
(0.9966) \\
{[2]}\end{array}$ \\
\hline \multirow{2}{*}{ 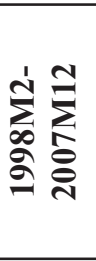 } & EUR & $\begin{array}{c}-0.22079 \\
(0.4126) \\
{[12]}\end{array}$ & $\begin{array}{c}-1.69023 \\
(0.0455) \\
{[12]}\end{array}$ & $\begin{array}{c}1.37685 \\
(0.9157) \\
{[12]}\end{array}$ & $\begin{array}{c}-0.62115 \\
(0.2673) \\
{[12]}\end{array}$ & $\begin{array}{c}1.53114 \\
(0.9371) \\
{[12]}\end{array}$ & $\begin{array}{c}-0.51669 \\
(0.3027) \\
{[12]}\end{array}$ \\
\hline & USD & $\begin{array}{c}3.18766 \\
(0.9993) \\
{[2]}\end{array}$ & $\begin{array}{c}2.95500 \\
(0.9984) \\
{[2]}\end{array}$ & $\begin{array}{c}3.47389 \\
(0.9997) \\
{[2]}\end{array}$ & $\begin{array}{c}2.63045 \\
(0.9957) \\
{[12]}\end{array}$ & $\begin{array}{c}3.22533 \\
(0.9994) \\
{[2]}\end{array}$ & $\begin{array}{c}2.99857 \\
(0.9986) \\
{[2]}\end{array}$ \\
\hline \multirow{2}{*}{ 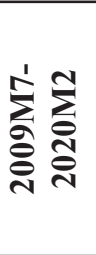 } & EUR & $\begin{array}{c}0.12119 \\
(0.5482) \\
{[12]} \\
\end{array}$ & $\begin{array}{c}-2.44164 \\
(0.0073) \\
{[12]} \\
\end{array}$ & $\begin{array}{c}1.34685 \\
(0.9110) \\
{[12]}\end{array}$ & $\begin{array}{c}-1.93355 \\
(0.0266) \\
{[12]}\end{array}$ & $\begin{array}{c}0.43103 \\
(0.6668) \\
{[12]}\end{array}$ & $\begin{array}{c}-2.08626 \\
(0.0185) \\
{[12]}\end{array}$ \\
\hline & USD & $\begin{array}{c}1.70367 \\
(0.9558) \\
{[2]}\end{array}$ & $\begin{array}{c}-2.90886 \\
(0.0018) \\
{[6]}\end{array}$ & $\begin{array}{c}1.61800 \\
(0.9472) \\
{[11]}\end{array}$ & $\begin{array}{c}-4.30083 \\
(0.0000) \\
{[7]}\end{array}$ & $\begin{array}{c}1.31767 \\
(0.9062) \\
{[7]}\end{array}$ & $\begin{array}{c}-3.09895 \\
(0.0010) \\
{[7]}\end{array}$ \\
\hline
\end{tabular}

Source: Authors calculation 
It can also be confirmed for both, the EUR and USD reference rates, in the post crises period when individual effects and individual linear trends are tested for all three information criteria. In the pre-crisis period there is vague evidence in favour of PPP for EUR reference rates only in one type of methodological approach.

Table 2. Results of Fisher ADF tests (Maddala and Wu $\chi^{2}$ statistic), deflator: CPI (All items)

\begin{tabular}{|c|c|c|c|c|c|c|c|}
\hline \multirow{3}{*}{ 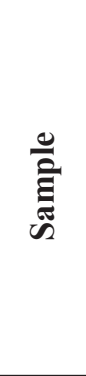 } & \multirow{3}{*}{ 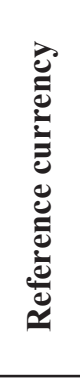 } & \multicolumn{2}{|c|}{$\begin{array}{c}\text { Schwarz information } \\
\text { criterion }\end{array}$} & \multicolumn{2}{|c|}{$\begin{array}{c}\text { Akaike information } \\
\text { criterion }\end{array}$} & \multicolumn{2}{|c|}{$\begin{array}{c}\text { Hannan-Quinn } \\
\text { information criterion }\end{array}$} \\
\hline & & $\begin{array}{l}\text { Individual } \\
\text { effects }\end{array}$ & $\begin{array}{c}\text { Individual } \\
\text { effects and } \\
\text { individual } \\
\text { linear trends } \\
\end{array}$ & $\begin{array}{c}\text { Individual } \\
\text { effects }\end{array}$ & 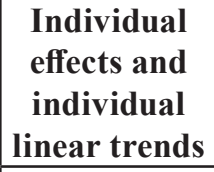 & $\begin{array}{c}\text { Individual } \\
\text { effects }\end{array}$ & $\begin{array}{c}\text { Individual } \\
\text { effects and } \\
\text { individual } \\
\text { linear trends }\end{array}$ \\
\hline & & $\begin{array}{c}\chi^{2} \\
\text { (p-value) } \\
\text { [no. of lags] }\end{array}$ & $\begin{array}{c}\chi^{2} \\
\text { (p-value) } \\
\text { [no. of lags] }\end{array}$ & $\begin{array}{c}\chi^{2} \\
\text { (p-value) } \\
\text { [no. of lags] }\end{array}$ & $\begin{array}{c}\chi^{2} \\
\text { (p-value) } \\
\text { [no. of lags] }\end{array}$ & $\begin{array}{c}\chi^{2} \\
\text { (p-value) } \\
\text { [no. of lags] }\end{array}$ & $\begin{array}{c}\chi^{2} \\
\text { (p-value) } \\
\text { [no. of lags] }\end{array}$ \\
\hline \multirow{2}{*}{ 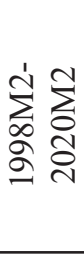 } & EUR & $\begin{array}{c}45.3029 \\
(0.0362) \\
{[12]} \\
\end{array}$ & $\begin{array}{c}21.7964 \\
(0.8613) \\
{[13]}\end{array}$ & $\begin{array}{c}45.0684 \\
(0.0380) \\
{[13]}\end{array}$ & $\begin{array}{c}22.2688 \\
(0.8441) \\
{[13]}\end{array}$ & $\begin{array}{c}39.8327 \\
(0.1081) \\
{[13]}\end{array}$ & $\begin{array}{c}19.6316 \\
(0.9258) \\
{[13]}\end{array}$ \\
\hline & USD & $\begin{array}{c}24.9020 \\
(0.7298) \\
{[2]} \\
\end{array}$ & $\begin{array}{c}10.6820 \\
(0.9996) \\
{[2]}\end{array}$ & $\begin{array}{c}23.6388 \\
(0.7881) \\
{[14]} \\
\end{array}$ & $\begin{array}{c}10.1051 \\
(0.9997) \\
{[14]} \\
\end{array}$ & $\begin{array}{c}24.5745 \\
(0.7454) \\
{[2]} \\
\end{array}$ & $\begin{array}{c}10.5821 \\
(0.9996) \\
{[2]}\end{array}$ \\
\hline \multirow{2}{*}{ 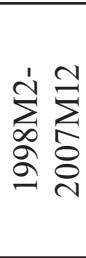 } & EUR & $\begin{array}{c}33.9613 \\
(0.2824) \\
{[12]} \\
\end{array}$ & $\begin{array}{c}49.9642 \\
(0.0125) \\
{[12]} \\
\end{array}$ & $\begin{array}{c}22.6006 \\
(0.8313) \\
{[12]} \\
\end{array}$ & $\begin{array}{c}36.1885 \\
(0.2020) \\
{[12]} \\
\end{array}$ & $\begin{array}{c}20.6318 \\
(0.8990) \\
{[12]} \\
\end{array}$ & $\begin{array}{c}35.4953 \\
(0.2251) \\
{[12]} \\
\end{array}$ \\
\hline & USD & $\begin{array}{c}11.7347 \\
(0.9989) \\
{[2]} \\
\end{array}$ & $\begin{array}{c}8.96620 \\
(0.9999) \\
{[2]} \\
\end{array}$ & $\begin{array}{c}11.2316 \\
(0.9993) \\
{[2]} \\
\end{array}$ & $\begin{array}{c}11.4221 \\
(0.9991) \\
{[12]} \\
\end{array}$ & $\begin{array}{c}11.4625 \\
(0.9991) \\
{[2]} \\
\end{array}$ & $\begin{array}{c}8.20071 \\
(1.0000) \\
{[2]}\end{array}$ \\
\hline \multirow{2}{*}{ 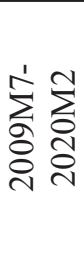 } & EUR & $\begin{array}{c}41.6653 \\
(0.0764) \\
{[12]} \\
\end{array}$ & $\begin{array}{c}60.4744 \\
(0.0008) \\
{[12]} \\
\end{array}$ & $\begin{array}{c}23.7992 \\
(0.7810) \\
{[12]} \\
\end{array}$ & $\begin{array}{c}55.5832 \\
(0.0030) \\
{[12]}\end{array}$ & $\begin{array}{c}40.0333 \\
(0.1042) \\
{[12]}\end{array}$ & $\begin{array}{c}57.0130 \\
(0.0021) \\
{[12]} \\
\end{array}$ \\
\hline & USD & $\begin{array}{c}15.6555 \\
(0.9855) \\
{[2]}\end{array}$ & $\begin{array}{c}48.6985 \\
(0.0169) \\
{[6]}\end{array}$ & $\begin{array}{c}19.5294 \\
(0.9282) \\
{[11]}\end{array}$ & $\begin{array}{c}62.2413 \\
(0.0005) \\
{[7]}\end{array}$ & $\begin{array}{c}19.7823 \\
(0.9221) \\
{[7]}\end{array}$ & $\begin{array}{c}49.7205 \\
(0.0133) \\
{[7]}\end{array}$ \\
\hline
\end{tabular}

Source: Authors calculation

The Fisher ADF tests result in two different test statistics. The Maddala and $\mathrm{Wu} \chi^{2}$ statistics are exhibited in Table 2, while the Choi $\mathrm{Z}$ statistics are presented in Table 3. Both sets of empirical estimates show very similar results. For the whole observed period, the PPP theory can be confirmed for EUR reference rates when individual effects are included for two out of three information criteria. In the pre-crisis period only one of the results supports the PPP for EUR reference rates. For the post-crisis period, EUR and USD reference rates gained support for PPP when the empirical test consists of individual effects and linear trends.

Both test statistics for Fisher PP tests (Table 4 and Table 5) result in the same conclusion for EUR reference rates: there is strong evidence in favour of PPP in the whole observed period and for the post-crises period since all results reject the null of a unit root. As for the pre-crisis period the PPP can be confirmed for EUR reference rates when individual effects and individual linear trends are included. While Maddala and $\mathrm{Wu} \chi^{2}$ statistic provides no evidence in favour of PPP in the case of the USD reference rates (Table 4), Choi Z statistic (Table 5) shows the validity of PPP in the case of USD rates for the post-crisis period when the individual effects and individual linear trends are incorporated. 
Table 3. Results of Fisher ADF tests (Choi Z statistic), deflator: CPI (All items)

\begin{tabular}{|c|c|c|c|c|c|c|c|}
\hline \multirow{3}{*}{ 思 } & \multirow{3}{*}{ 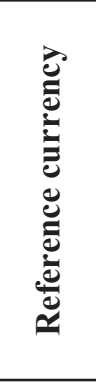 } & \multicolumn{2}{|c|}{$\begin{array}{c}\text { Schwarz information } \\
\text { criterion }\end{array}$} & \multicolumn{2}{|c|}{$\begin{array}{c}\text { Akaike information } \\
\text { criterion }\end{array}$} & \multicolumn{2}{|c|}{$\begin{array}{c}\text { Hannan-Quinn } \\
\text { information criterion }\end{array}$} \\
\hline & & $\begin{array}{l}\text { Individual } \\
\text { effects }\end{array}$ & $\begin{array}{c}\text { Individual } \\
\text { effects and } \\
\text { individual } \\
\text { linear trends } \\
\end{array}$ & $\begin{array}{l}\text { Individual } \\
\text { effects }\end{array}$ & \begin{tabular}{|c|} 
Individual \\
effects and \\
individual \\
linear trends \\
\end{tabular} & $\begin{array}{l}\text { Individual } \\
\text { effects }\end{array}$ & $\begin{array}{l}\text { Individual } \\
\text { effects and } \\
\text { individual } \\
\text { linear trends }\end{array}$ \\
\hline & & $\begin{array}{c}\mathrm{Z} \\
\text { (p-value) } \\
\text { [no. of lags] }\end{array}$ & $\begin{array}{c}\mathrm{Z} \\
\text { (p-value) } \\
\text { [no. of lags] }\end{array}$ & $\begin{array}{c}\mathrm{Z} \\
\text { (p-value) } \\
\text { [no. of lags] }\end{array}$ & $\begin{array}{c}\mathrm{Z} \\
\text { (p-value) } \\
\text { [no. of lags] }\end{array}$ & $\begin{array}{c}\mathrm{Z} \\
\text { (p-value) } \\
\text { [no. of lags] }\end{array}$ & $\begin{array}{c}\mathrm{Z} \\
\text { (p-value) } \\
\text { [no. of lags] }\end{array}$ \\
\hline \multirow{2}{*}{ 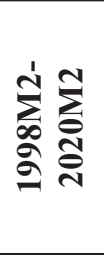 } & EUR & $\begin{array}{c}-1.58339 \\
(0.0567) \\
{[12]} \\
\end{array}$ & $\begin{array}{c}1.67251 \\
(0.9528) \\
{[13]} \\
\end{array}$ & $\begin{array}{c}-1.55154 \\
(0.0604) \\
{[13]}\end{array}$ & $\begin{array}{c}1.82242 \\
(0.9658) \\
{[13]} \\
\end{array}$ & $\begin{array}{c}-1.23349 \\
(0.1087) \\
{[13]}\end{array}$ & $\begin{array}{c}1.93765 \\
(0.9737) \\
{[13]} \\
\end{array}$ \\
\hline & USD & $\begin{array}{c}-0.33392 \\
(0.3692) \\
{[2]}\end{array}$ & $\begin{array}{c}2.83401 \\
(0.9977) \\
{[2]} \\
\end{array}$ & $\begin{array}{c}-0.13575 \\
(0.4460) \\
{[14]}\end{array}$ & $\begin{array}{c}3.08415 \\
(0.9990) \\
{[14]} \\
\end{array}$ & $\begin{array}{c}-0.26737 \\
(0.3946) \\
{[2]}\end{array}$ & $\begin{array}{c}2.91147 \\
(0.9982) \\
{[2]} \\
\end{array}$ \\
\hline \multirow{2}{*}{ 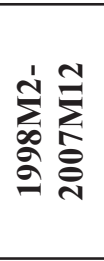 } & EUR & $\begin{array}{c}-0.16494 \\
(0.4345) \\
{[12]} \\
\end{array}$ & $\begin{array}{c}-1.61270 \\
(0.0534) \\
{[12]} \\
\end{array}$ & $\begin{array}{c}1.54444 \\
(0.9388) \\
{[12]} \\
\end{array}$ & $\begin{array}{c}-0.49544 \\
(0.3101) \\
{[12]}\end{array}$ & $\begin{array}{c}1.70288 \\
(0.9557) \\
{[12]} \\
\end{array}$ & $\begin{array}{c}-0.39520 \\
(0.3463) \\
{[12]}\end{array}$ \\
\hline & USD & $\begin{array}{c}3.18795 \\
(0.9993) \\
{[2]} \\
\end{array}$ & $\begin{array}{c}3.07571 \\
(0.9989) \\
{[2]} \\
\end{array}$ & $\begin{array}{c}3.46531 \\
(0.9997) \\
{[2]} \\
\end{array}$ & $\begin{array}{c}2.83750 \\
(0.9977) \\
{[12]} \\
\end{array}$ & $\begin{array}{c}3.23543 \\
(0.9994) \\
{[2]} \\
\end{array}$ & $\begin{array}{c}3.15053 \\
(0.9992) \\
{[2]} \\
\end{array}$ \\
\hline \multirow{2}{*}{ 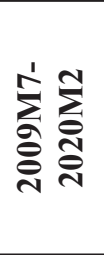 } & EUR & $\begin{array}{c}0.18887 \\
(0.5749) \\
{[12]} \\
\end{array}$ & $\begin{array}{c}-2.29946 \\
(0.0107) \\
{[12]} \\
\end{array}$ & $\begin{array}{c}1.57691 \\
(0.9426) \\
{[12]} \\
\end{array}$ & $\begin{array}{c}-1.67012 \\
(0.0474) \\
{[12]} \\
\end{array}$ & $\begin{array}{c}0.53108 \\
(0.7023) \\
{[12]} \\
\end{array}$ & $\begin{array}{c}-1.90085 \\
(0.0287) \\
{[12]}\end{array}$ \\
\hline & USD & $\begin{array}{c}1.81983 \\
(0.9656) \\
{[2]}\end{array}$ & $\begin{array}{c}-3.00930 \\
(0.0013) \\
{[6]}\end{array}$ & $\begin{array}{c}1.90112 \\
(0.9714) \\
{[11]}\end{array}$ & $\begin{array}{c}-4.30663 \\
(0.0000) \\
{[7]}\end{array}$ & $\begin{array}{c}1.46297 \\
(0.9283) \\
{[7]}\end{array}$ & $\begin{array}{c}-3.18327 \\
(0.0007) \\
{[7]}\end{array}$ \\
\hline
\end{tabular}

Source: Authors calculation

Table 4. Results of Fisher PP tests (Maddala and $\mathrm{Wu} \chi^{2}$ statistic), deflator: CPI (All items)

\begin{tabular}{|c|c|c|c|c|c|c|c|}
\hline \multirow{3}{*}{ 产 } & \multirow{3}{*}{ 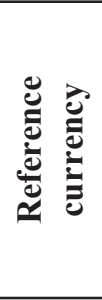 } & \multicolumn{2}{|c|}{ Bartlett kernel } & \multicolumn{2}{|c|}{ Parzen kernel } & \multicolumn{2}{|c|}{ Quadratic spectral kernel } \\
\hline & & $\begin{array}{l}\text { Individual } \\
\text { effects }\end{array}$ & $\begin{array}{c}\text { Individual } \\
\text { effects and } \\
\text { individual } \\
\text { linear trends }\end{array}$ & $\begin{array}{c}\text { Individual } \\
\text { effects }\end{array}$ & \begin{tabular}{|c|} 
Individual \\
effects and \\
individual \\
linear trends
\end{tabular} & $\begin{array}{c}\text { Individual } \\
\text { effects }\end{array}$ & $\begin{array}{l}\text { Individual } \\
\text { effects and } \\
\text { individual } \\
\text { linear trends }\end{array}$ \\
\hline & & $\begin{array}{c}\chi^{2} \\
\text { (p-value) }\end{array}$ & $\begin{array}{c}\chi^{2} \\
\text { (p-value) } \\
\end{array}$ & $\begin{array}{c}\chi^{2} \\
\text { (p-value) }\end{array}$ & $\begin{array}{c}\chi^{2} \\
\text { (p-value) } \\
\end{array}$ & $\begin{array}{c}\chi^{2} \\
\text { (p-value) }\end{array}$ & $\begin{array}{c}\chi^{2} \\
\text { (p-value) }\end{array}$ \\
\hline \multirow{2}{*}{ 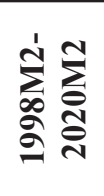 } & EUR & $\begin{array}{l}73.9525 \\
(0.0000)\end{array}$ & $\begin{array}{l}85.5627 \\
(0.0000)\end{array}$ & $\begin{array}{l}73.5883 \\
(0.0000)\end{array}$ & $\begin{array}{l}79.2642 \\
(0.0000)\end{array}$ & $\begin{array}{l}72.9475 \\
(0.0000)\end{array}$ & $\begin{array}{l}75.4382 \\
(0.0000)\end{array}$ \\
\hline & USD & $\begin{array}{l}21.4680 \\
(0.8727)\end{array}$ & $\begin{array}{c}8.75730 \\
(0.9999)\end{array}$ & $\begin{array}{l}22.4144 \\
(0.8385)\end{array}$ & $\begin{array}{c}9.17347 \\
(0.9999)\end{array}$ & $\begin{array}{l}22.2296 \\
(0.8456)\end{array}$ & $\begin{array}{l}9.18427 \\
(0.9999)\end{array}$ \\
\hline \multirow{2}{*}{ 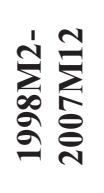 } & EUR & $\begin{array}{c}35.1676 \\
(0.2366) \\
\end{array}$ & $\begin{array}{c}67.4171 \\
(0.0001)\end{array}$ & $\begin{array}{l}33.8152 \\
(0.2883)\end{array}$ & $\begin{array}{l}69.7449 \\
(0.0001)\end{array}$ & $\begin{array}{l}33.7657 \\
(0.2903)\end{array}$ & $\begin{array}{l}70.6268 \\
(0.0000)\end{array}$ \\
\hline & USD & $\begin{array}{l}10.3054 \\
(0.9997)\end{array}$ & $\begin{array}{l}5.61812 \\
(1.0000)\end{array}$ & $\begin{array}{l}10.8064 \\
(0.9995)\end{array}$ & $\begin{array}{l}6.27148 \\
(1.0000)\end{array}$ & $\begin{array}{c}10.7553 \\
(0.9995)\end{array}$ & $\begin{array}{l}6.32378 \\
(1.0000)\end{array}$ \\
\hline \multirow{2}{*}{ 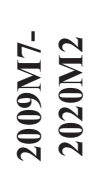 } & EUR & $\begin{array}{c}78.9056 \\
(0.0000)\end{array}$ & $\begin{array}{c}129.676 \\
(0.0000)\end{array}$ & $\begin{array}{c}77.4170 \\
(0.0000)\end{array}$ & $\begin{array}{l}135.297 \\
(0.0000)\end{array}$ & $\begin{array}{l}74.5540 \\
(0.0000)\end{array}$ & $\begin{array}{l}130.740 \\
(0.0000)\end{array}$ \\
\hline & USD & $\begin{array}{l}15.6936 \\
(0.9852)\end{array}$ & $\begin{array}{l}37.2959 \\
(0.1687)\end{array}$ & $\begin{array}{l}16.4785 \\
(0.9783)\end{array}$ & $\begin{array}{l}40.0229 \\
(0.1044)\end{array}$ & $\begin{array}{l}16.2562 \\
(0.9805)\end{array}$ & $\begin{array}{l}39.9550 \\
(0.1057)\end{array}$ \\
\hline
\end{tabular}

Source: Authors calculation 
Table 5. Results of Fisher PP tests (Choi Z statistic), deflator: CPI (All items)

\begin{tabular}{|c|c|c|c|c|c|c|c|}
\hline \multirow{3}{*}{ 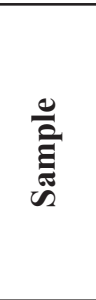 } & \multirow{3}{*}{ 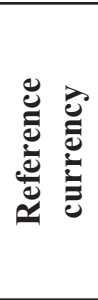 } & \multicolumn{2}{|c|}{ Bartlett kernel } & \multicolumn{2}{|c|}{ Parzen kernel } & \multicolumn{2}{|c|}{ Quadratic spectral kernel } \\
\hline & & $\begin{array}{c}\text { Individual } \\
\text { effects }\end{array}$ & $\begin{array}{c}\text { Individual } \\
\text { effects and } \\
\text { individual } \\
\text { linear trends } \\
\end{array}$ & $\begin{array}{l}\text { Individual } \\
\text { effects }\end{array}$ & $\begin{array}{c}\text { Individual } \\
\text { effects and } \\
\text { individual } \\
\text { linear trends } \\
\end{array}$ & $\begin{array}{c}\text { Individual } \\
\text { effects }\end{array}$ & $\begin{array}{c}\text { Individual } \\
\text { effects and } \\
\text { individual } \\
\text { linear trends }\end{array}$ \\
\hline & & $\begin{array}{c}\mathrm{Z} \\
\text { (p-value) }\end{array}$ & $\begin{array}{c}\mathbf{Z} \\
\text { (p-value) } \\
\end{array}$ & $\begin{array}{c}\mathrm{Z} \\
\text { (p-value) }\end{array}$ & $\begin{array}{c}\mathrm{Z} \\
\text { (p-value) }\end{array}$ & $\begin{array}{c}Z \\
\text { (p-value) }\end{array}$ & $\begin{array}{c}Z \\
\text { (p-value) }\end{array}$ \\
\hline \multirow{2}{*}{ 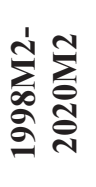 } & EUR & $\begin{array}{l}-3.48665 \\
(0.0002)\end{array}$ & $\begin{array}{l}-2.34629 \\
(0.0095)\end{array}$ & $\begin{array}{l}-3.69304 \\
(0.0001)\end{array}$ & $\begin{array}{c}-2.54400 \\
(0.0055)\end{array}$ & $\begin{array}{c}-3.66546 \\
(0.0001)\end{array}$ & $\begin{array}{l}-2.45717 \\
(0.0070)\end{array}$ \\
\hline & USD & $\begin{array}{l}0.19985 \\
(0.5792) \\
\end{array}$ & $\begin{array}{l}3.46722 \\
(0.9997) \\
\end{array}$ & $\begin{array}{l}0.03900 \\
(0.5156) \\
\end{array}$ & $\begin{array}{l}3.31634 \\
(0.9995) \\
\end{array}$ & $\begin{array}{l}0.07284 \\
(0.5290)\end{array}$ & $\begin{array}{l}3.33208 \\
(0.9996) \\
\end{array}$ \\
\hline \multirow{2}{*}{ 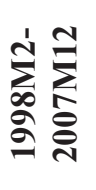 } & EUR & $\begin{array}{l}0.32438 \\
(0.6272)\end{array}$ & $\begin{array}{l}-3.45419 \\
(0.0003)\end{array}$ & $\begin{array}{l}0.42849 \\
(0.6659)\end{array}$ & $\begin{array}{l}-3.52678 \\
(0.0002)\end{array}$ & $\begin{array}{l}0.44531 \\
(0.6720)\end{array}$ & $\begin{array}{l}-3.59375 \\
(0.0002)\end{array}$ \\
\hline & USD & $\begin{array}{l}4.10637 \\
(1.0000)\end{array}$ & $\begin{array}{l}4.06173 \\
(1.0000)\end{array}$ & $\begin{array}{l}3.82895 \\
(0.9999)\end{array}$ & $\begin{array}{l}3.81421 \\
(0.9999)\end{array}$ & $\begin{array}{l}3.85495 \\
(0.9999)\end{array}$ & $\begin{array}{l}3.81976 \\
(0.9999)\end{array}$ \\
\hline \multirow{2}{*}{ 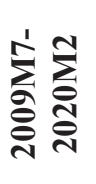 } & EUR & $\begin{array}{c}-2.56661 \\
(0.0051)\end{array}$ & $\begin{array}{l}-6.41359 \\
(0.0000)\end{array}$ & $\begin{array}{l}-2.69782 \\
(0.0035)\end{array}$ & $\begin{array}{l}-6.87621 \\
(0.0000)\end{array}$ & $\begin{array}{l}-2.37483 \\
(0.0088)\end{array}$ & $\begin{array}{l}-6.71499 \\
(0.0000)\end{array}$ \\
\hline & USD & $\begin{array}{l}1.98790 \\
(0.9766)\end{array}$ & $\begin{array}{l}-1.97841 \\
(0.0239)\end{array}$ & $\begin{array}{c}1.91723 \\
(0.9724)\end{array}$ & $\begin{array}{r}-2.29807 \\
(0.0108)\end{array}$ & $\begin{array}{l}1.92923 \\
(0.9731)\end{array}$ & $\begin{array}{c}-2.27819 \\
(0.0114)\end{array}$ \\
\hline
\end{tabular}

Source: Authors calculation

Table 6. Results of Levin, Lin and Chu test, deflator: CPI (All items)

\begin{tabular}{|c|c|c|c|c|c|c|c|}
\hline \multirow{3}{*}{ 产 } & \multirow{3}{*}{ 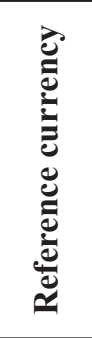 } & \multicolumn{2}{|c|}{ Bartlett kernel } & \multicolumn{2}{|c|}{ Parzen kernel } & \multicolumn{2}{|c|}{ Quadratic spectral kernel } \\
\hline & & $\begin{array}{l}\text { Individual } \\
\text { effects }\end{array}$ & $\begin{array}{c}\text { Individual } \\
\text { effects and } \\
\text { individual } \\
\text { linear trends }\end{array}$ & $\begin{array}{c}\text { Individual } \\
\text { effects }\end{array}$ & \begin{tabular}{|c|} 
Individual \\
effects and \\
individual \\
linear trends
\end{tabular} & $\begin{array}{c}\text { Individual } \\
\text { effects }\end{array}$ & $\begin{array}{l}\text { Individual } \\
\text { effects and } \\
\text { individual } \\
\text { linear trends }\end{array}$ \\
\hline & & $\begin{array}{c}\mathrm{t}^{*} \\
\text { (p-value) } \\
\text { [no. of lags] }\end{array}$ & $\begin{array}{c}* \\
\text { (p-value) } \\
\text { [no. of lags] }\end{array}$ & $\begin{array}{c}t^{*} \\
\text { (p-value) } \\
{[\text { no. of lags] }}\end{array}$ & $\begin{array}{c}* \\
\text { (p-value) } \\
\text { [no. of lags] } \\
\end{array}$ & $\begin{array}{c}t^{*} \\
\text { (p-value) } \\
\text { [no. of lags] }\end{array}$ & $\begin{array}{c}\mathrm{t}^{*} \\
\text { (p-value) } \\
\text { [no. of lags] }\end{array}$ \\
\hline \multirow{2}{*}{ 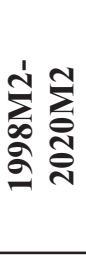 } & EUR & $\begin{array}{c}-2.29486 \\
(0.0109) \\
{[12]} \\
\end{array}$ & $\begin{array}{c}-0.05973 \\
(0.4762) \\
{[13]} \\
\end{array}$ & $\begin{array}{c}-2.66657 \\
(0.0038) \\
{[12]} \\
\end{array}$ & $\begin{array}{c}-0.52582 \\
(0.2995) \\
{[13]}\end{array}$ & $\begin{array}{c}-2.69816 \\
(0.0035) \\
{[12]}\end{array}$ & $\begin{array}{c}-0.41396 \\
(0.3395) \\
{[13]} \\
\end{array}$ \\
\hline & USD & $\begin{array}{c}-0.10730 \\
(0.4573) \\
{[2]} \\
\end{array}$ & $\begin{array}{c}0.79748 \\
(0.7874) \\
{[2]} \\
\end{array}$ & $\begin{array}{c}-0.02714 \\
(0.4892) \\
{[2]} \\
\end{array}$ & $\begin{array}{c}0.88572 \\
(0.8121) \\
{[2]}\end{array}$ & $\begin{array}{c}-0.04750 \\
(0.4811) \\
{[2]} \\
\end{array}$ & $\begin{array}{c}0.85343 \\
(0.8033) \\
{[2]} \\
\end{array}$ \\
\hline \multirow{2}{*}{ 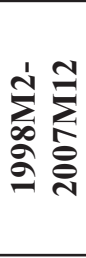 } & EUR & $\begin{array}{c}-1.45797 \\
(0.0724) \\
{[12]} \\
\end{array}$ & $\begin{array}{c}-2.16598 \\
(0.0152) \\
{[12]} \\
\end{array}$ & $\begin{array}{c}-1.62001 \\
(0.0526) \\
{[12]} \\
\end{array}$ & $\begin{array}{c}-2.62196 \\
(0.0044) \\
{[12]} \\
\end{array}$ & $\begin{array}{c}-1.58540 \\
(0.0564) \\
{[12]} \\
\end{array}$ & $\begin{array}{c}-2.48300 \\
(0.0065) \\
{[12]}\end{array}$ \\
\hline & USD & $\begin{array}{c}1.71408 \\
(0.9567) \\
{[2]} \\
\end{array}$ & $\begin{array}{c}-0.08544 \\
(0.4660) \\
{[2]} \\
\end{array}$ & $\begin{array}{c}1.90866 \\
(0.9718) \\
{[2]} \\
\end{array}$ & $\begin{array}{c}0.02018 \\
(0.5080) \\
{[2]} \\
\end{array}$ & $\begin{array}{c}1.92027 \\
(0.9726) \\
{[2]}\end{array}$ & $\begin{array}{c}0.03261 \\
(0.5130) \\
{[2]}\end{array}$ \\
\hline \multirow{2}{*}{ 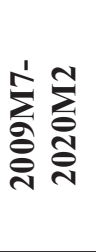 } & EUR & $\begin{array}{c}0.68995 \\
(0.7549) \\
{[12]} \\
\end{array}$ & $\begin{array}{c}-2.19223 \\
(0.0142) \\
{[12]} \\
\end{array}$ & $\begin{array}{c}0.17725 \\
(0.5703) \\
{[12]} \\
\end{array}$ & $\begin{array}{c}-3.69549 \\
(0.0001) \\
{[12]} \\
\end{array}$ & $\begin{array}{c}0.12456 \\
(0.5496) \\
{[12]}\end{array}$ & $\begin{array}{c}-3.69016 \\
(0.0001) \\
{[12]}\end{array}$ \\
\hline & USD & $\begin{array}{c}0.70696 \\
(0.7602) \\
{[2]}\end{array}$ & $\begin{array}{c}-1.12697 \\
(0.1299) \\
{[6]}\end{array}$ & $\begin{array}{c}0.77794 \\
(0.7817) \\
{[2]}\end{array}$ & $\begin{array}{c}-0.88959 \\
(0.1868) \\
{[6]}\end{array}$ & $\begin{array}{c}0.80470 \\
(0.7895) \\
{[2]}\end{array}$ & $\begin{array}{c}-0.77585 \\
(0.2189) \\
{[6]}\end{array}$ \\
\hline
\end{tabular}

Notes: The number of lags used in each cross-section ADF regression $\left(\mathrm{p}_{\mathrm{i}}\right)$ was defined by the Schwarz information criterion. Computation was conducted with Newey-West bandwidth selection.

Source: Authors calculation 
Results of Levin, Lin and Chu test (Table 6) show evidence for PPP in EUR reference rates, which recorded very strong support for PPP in the pre-crisis period as all test results reject the null of a unit root. In the whole period, PPP can be confirmed for individual trends, while in the post-crises period the EUR reference rates behave according to PPP theory when individual effects and individual linear trends are considered. However, there is no confirmation of PPP in case of USD reference rates according to Levin, Lin and Chu test when using general CPI.

Breitung test outcomes are displayed in Table 7, where there is no evidence in favour of PPP in the case of EUR reference rates in none of the three periods. On the other hand, the PPP is supported in the case of USD reference rates in the whole observed period and the post-crisis period for all three information criteria applied in determining the lags.

Table 7. Results of Breitung test, deflator: CPI (All items)

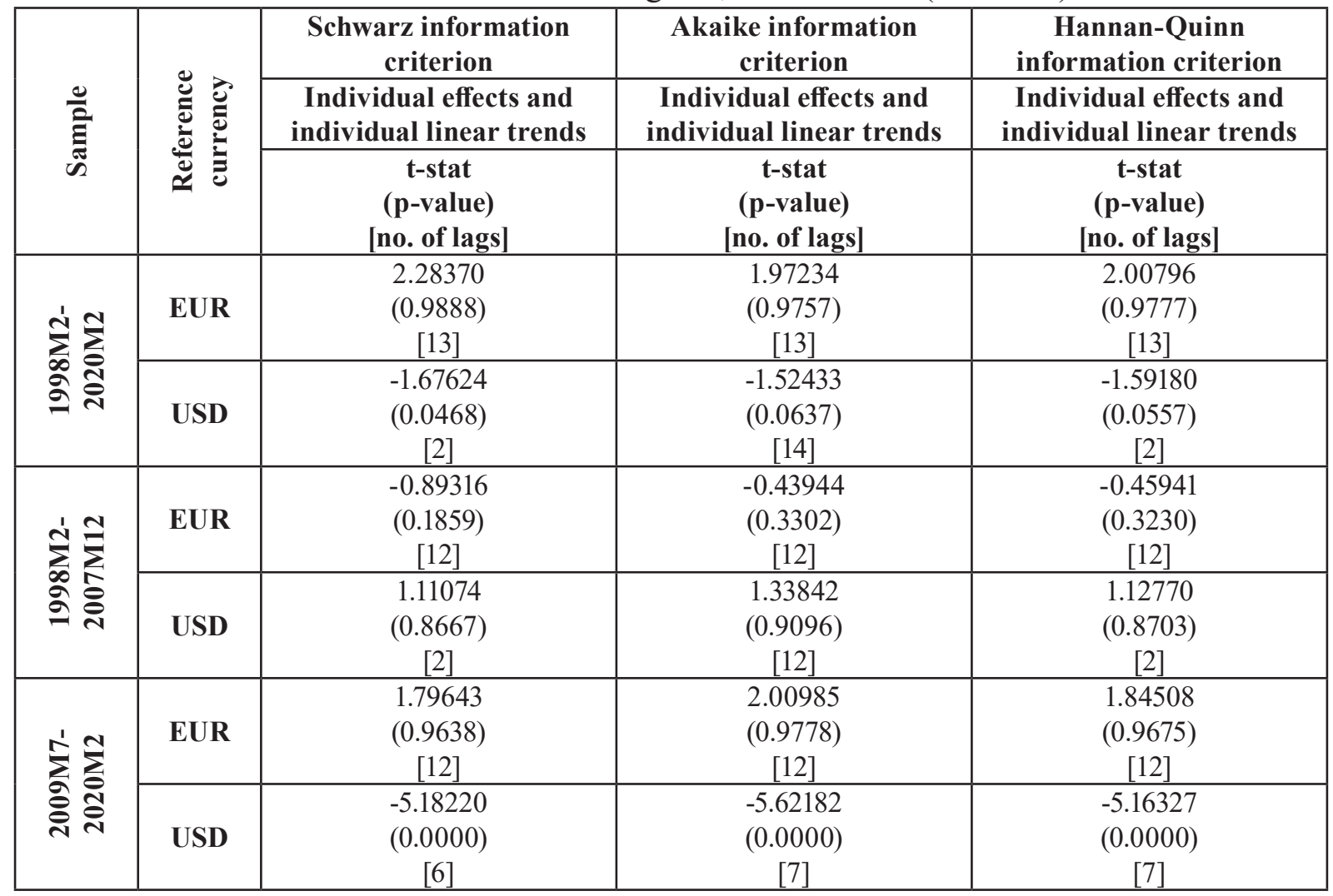

Source: Authors calculation

\subsection{Results based on consumer price indices for hotels and restaurants}

When real exchange rates are calculated by nominal exchange rates of EUR and CPI for hotels and restaurants, there is very strong support in favour of PPP according to Im, Pesaran and Shin test (Table 8), as for all combinations of test parameters the null of a unit root is strongly rejected at a very high significance level. The same test shows some support for PPP in the whole period also for the USD reference rate, namely the null is rejected when Schwarz information criterion is taken into account along with the individual trends. In the pre-crisis period USD reference rates do not follow the PPP characteristics, while in the post-crises period the individual effects and individual linear trends result in rejecting the null for all information criteria providing evidence in favour of PPP, also in the case of USD rates. 
Table 8. Results of Im, Pesaran and Shin test, deflator: CPI (Hotels and restaurants)

\begin{tabular}{|c|c|c|c|c|c|c|c|}
\hline \multirow{3}{*}{ 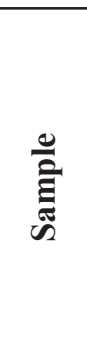 } & \multirow{3}{*}{ 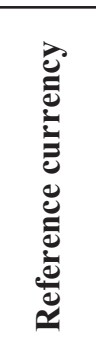 } & \multicolumn{2}{|c|}{$\begin{array}{c}\text { Schwarz information } \\
\text { criterion }\end{array}$} & \multicolumn{2}{|c|}{$\begin{array}{c}\text { Akaike information } \\
\text { criterion }\end{array}$} & \multicolumn{2}{|c|}{$\begin{array}{l}\text { Hannan-Quinn information } \\
\text { criterion }\end{array}$} \\
\hline & & $\begin{array}{c}\text { Individual } \\
\text { effects }\end{array}$ & $\begin{array}{l}\text { Individual } \\
\text { effects and } \\
\text { individual } \\
\text { linear trends }\end{array}$ & $\begin{array}{l}\text { Individual } \\
\text { effects }\end{array}$ & $\begin{array}{l}\text { Individual } \\
\text { effects and } \\
\text { individual } \\
\text { linear trends }\end{array}$ & $\begin{array}{c}\text { Individual } \\
\text { effects }\end{array}$ & $\begin{array}{l}\text { Individual } \\
\text { effects and } \\
\text { individual } \\
\text { linear trends }\end{array}$ \\
\hline & & $\begin{array}{c}\text { W-stat } \\
\text { (p-value) } \\
\text { [no. of lags] }\end{array}$ & $\begin{array}{c}\text { W-stat } \\
\text { (p-value) } \\
{[\text { no. of lags] }}\end{array}$ & $\begin{array}{c}\text { W-stat } \\
\text { (p-value) } \\
{[\text { no. of lags] }}\end{array}$ & $\begin{array}{c}\text { W-stat } \\
\text { (p-value) } \\
{[\text { no. of lags] }}\end{array}$ & $\begin{array}{c}\text { W-stat } \\
\text { (p-value) } \\
\text { [no. of lags] }\end{array}$ & $\begin{array}{c}\text { W-stat } \\
\text { (p-value) } \\
\text { [no. of lags] }\end{array}$ \\
\hline \multirow{2}{*}{ 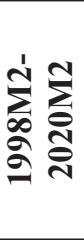 } & EUR & $\begin{array}{c}-7.78782 \\
(0.0000) \\
{[15]}\end{array}$ & $\begin{array}{c}-8.11868 \\
(0.0000) \\
{[15]}\end{array}$ & $\begin{array}{c}-7.11634 \\
(0.0000) \\
{[15]}\end{array}$ & $\begin{array}{c}-7.57937 \\
(0.0000) \\
{[15]}\end{array}$ & $\begin{array}{c}-7.86337 \\
(0.0000) \\
{[15]}\end{array}$ & $\begin{array}{c}8.22296 \\
(0.0000) \\
{[15]}\end{array}$ \\
\hline & USD & $\begin{array}{c}-1.35315 \\
(0.0880) \\
{[12]}\end{array}$ & $\begin{array}{c}0.71219 \\
(0.7618) \\
{[12]}\end{array}$ & $\begin{array}{c}-0.88800 \\
(0.1873) \\
{[14]}\end{array}$ & $\begin{array}{c}1.22082 \\
(0.8889) \\
{[14]}\end{array}$ & $\begin{array}{c}-0.86521 \\
(0.1935) \\
{[14]}\end{array}$ & $\begin{array}{c}1.11441 \\
(0.8674) \\
{[13]}\end{array}$ \\
\hline \multirow{2}{*}{ 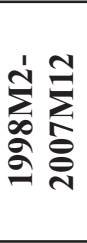 } & EUR & $\begin{array}{c}-6.96504 \\
(0.0000) \\
{[12]}\end{array}$ & $\begin{array}{c}-4.60655 \\
(0.0000) \\
{[12]}\end{array}$ & $\begin{array}{c}-4.88871 \\
(0.0000) \\
{[12]}\end{array}$ & $\begin{array}{c}3.24592 \\
(0.0006) \\
{[12]}\end{array}$ & $\begin{array}{c}-6.91165 \\
(0.0000) \\
{[12]}\end{array}$ & $\begin{array}{c}-5.35154 \\
(0.0000) \\
{[12]} \\
\end{array}$ \\
\hline & USD & $\begin{array}{c}2.57608 \\
(0.9950) \\
{[12]}\end{array}$ & $\begin{array}{c}2.35964 \\
(0.9909) \\
{[12]}\end{array}$ & $\begin{array}{c}2.62629 \\
(0.9957) \\
{[12]}\end{array}$ & $\begin{array}{c}1.64659 \\
(0.9502) \\
{[12]}\end{array}$ & $\begin{array}{c}2.53650 \\
(0.9944) \\
{[12]}\end{array}$ & $\begin{array}{c}1.73435 \\
(0.9586) \\
{[12]}\end{array}$ \\
\hline \multirow{2}{*}{ 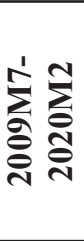 } & EUR & $\begin{array}{c}-6.23387 \\
(0.0000) \\
{[12]}\end{array}$ & $\begin{array}{c}-6.81942 \\
(0.0000) \\
{[12]}\end{array}$ & $\begin{array}{c}-5.9635 \\
(0.0000) \\
{[12]}\end{array}$ & $\begin{array}{c}-6.94900 \\
(0.0000) \\
{[12]}\end{array}$ & $\begin{array}{c}-6.34530 \\
(0.0000) \\
{[12]}\end{array}$ & $\begin{array}{c}-6.90124 \\
(0.0000) \\
{[12]}\end{array}$ \\
\hline & USD & $\begin{array}{c}0.04686 \\
(0.5187) \\
{[12]}\end{array}$ & $\begin{array}{c}-3.67858 \\
(0.0001) \\
{[12]}\end{array}$ & $\begin{array}{c}0.33968 \\
(0.6330) \\
{[12]}\end{array}$ & $\begin{array}{c}-3.64845 \\
(0.0001) \\
{[12]}\end{array}$ & $\begin{array}{c}-0.01562 \\
(0.4938) \\
{[12]}\end{array}$ & $\begin{array}{c}-3.74196 \\
(0.0001) \\
{[12]}\end{array}$ \\
\hline
\end{tabular}

Source: Authors calculation

Table 9. Results of Fisher ADF tests (Maddala and $\mathrm{Wu} \chi^{2}$ statistic), deflator: CPI (Hotels and restaurants)

\begin{tabular}{|c|c|c|c|c|c|c|c|}
\hline \multirow{3}{*}{ 苂 } & \multirow{3}{*}{ 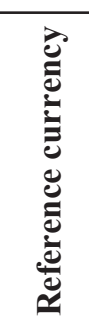 } & \multicolumn{2}{|c|}{$\begin{array}{c}\text { Schwarz information cri- } \\
\text { terion }\end{array}$} & \multicolumn{2}{|c|}{$\begin{array}{l}\text { Akaike information crite- } \\
\text { rion }\end{array}$} & \multicolumn{2}{|c|}{$\begin{array}{l}\text { Hannan-Quinn information } \\
\text { criterion }\end{array}$} \\
\hline & & $\begin{array}{l}\text { Individual } \\
\text { effects }\end{array}$ & $\begin{array}{l}\text { Individual } \\
\text { effects and } \\
\text { individual } \\
\text { linear trends }\end{array}$ & $\begin{array}{l}\text { Individual } \\
\text { effects }\end{array}$ & $\begin{array}{l}\text { Individual } \\
\text { effects and } \\
\text { individual } \\
\text { linear trends }\end{array}$ & $\begin{array}{l}\text { Individual } \\
\text { effects }\end{array}$ & $\begin{array}{l}\text { Individual } \\
\text { effects and } \\
\text { individual } \\
\text { linear trends }\end{array}$ \\
\hline & & $\begin{array}{l}\chi^{2} \text { (p-value) } \\
\text { [no. of lags] }\end{array}$ & $\begin{array}{l}\chi^{2} \text { (p-value) } \\
{[\text { no. of lags] }}\end{array}$ & $\begin{array}{l}\chi^{2} \text { (p-value) } \\
\text { [no. of lags] }\end{array}$ & $\begin{array}{l}\chi^{2} \text { (p-value) } \\
\text { [no. of lags] }\end{array}$ & $\begin{array}{l}\chi^{2} \text { (p-value) } \\
\text { [no. of lags] }\end{array}$ & $\begin{array}{l}\chi^{2} \text { (p-value) } \\
\text { [no. of lags] }\end{array}$ \\
\hline \multirow{2}{*}{ 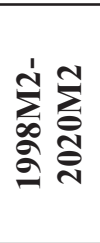 } & EUR & $\begin{array}{c}140.945 \\
(0.0000) \\
{[15]}\end{array}$ & $\begin{array}{c}133.944 \\
(0.0000) \\
{[15]}\end{array}$ & $\begin{array}{c}120.335 \\
(0.0000) \\
{[15]}\end{array}$ & $\begin{array}{c}118.068 \\
(0.0000) \\
{[15]}\end{array}$ & $\begin{array}{c}141.841 \\
(0.0000) \\
{[15]}\end{array}$ & $\begin{array}{c}134.776 \\
(0.0000) \\
{[15]}\end{array}$ \\
\hline & USD & $\begin{array}{c}21.7356 \\
(0.3550) \\
{[12]} \\
\end{array}$ & $\begin{array}{c}12.4383 \\
(0.9002) \\
{[12]} \\
\end{array}$ & $\begin{array}{c}18.4204 \\
(0.5597) \\
{[14]} \\
\end{array}$ & $\begin{array}{c}10.2246 \\
(0.9639) \\
{[14]} \\
\end{array}$ & $\begin{array}{c}18.1975 \\
(0.5744) \\
{[14]} \\
\end{array}$ & $\begin{array}{c}11.2069 \\
(0.9407) \\
{[13]} \\
\end{array}$ \\
\hline \multirow{2}{*}{ 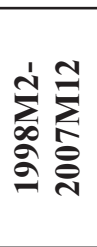 } & EUR & $\begin{array}{c}114.169 \\
(0.0000) \\
{[12]}\end{array}$ & $\begin{array}{c}88.7812 \\
(0.0000) \\
{[12]}\end{array}$ & $\begin{array}{c}76.1966 \\
(0.0000) \\
{[12]}\end{array}$ & $\begin{array}{c}59.9558 \\
(0.0000) \\
{[12]}\end{array}$ & $\begin{array}{c}114.025 \\
(0.0000) \\
{[12]}\end{array}$ & $\begin{array}{c}95.9216 \\
(0.0000) \\
{[12]}\end{array}$ \\
\hline & USD & $\begin{array}{c}13.2424 \\
(0.8667) \\
{[12]}\end{array}$ & $\begin{array}{c}5.82109 \\
(0.9991) \\
{[12]}\end{array}$ & $\begin{array}{c}11.2021 \\
(0.9408) \\
{[12]}\end{array}$ & $\begin{array}{c}11.6864 \\
(0.9264) \\
{[12]}\end{array}$ & $\begin{array}{c}11.0220 \\
(0.9457) \\
{[12]}\end{array}$ & $\begin{array}{c}11.6413 \\
(0.9279) \\
{[12]}\end{array}$ \\
\hline \multirow{2}{*}{ 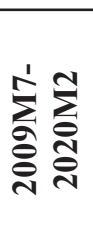 } & EUR & $\begin{array}{c}124.322 \\
(0.0000) \\
{[12]}\end{array}$ & $\begin{array}{c}116.373 \\
(0.0000) \\
{[12]}\end{array}$ & $\begin{array}{l}120.467 \\
(0.0000) \\
\end{array}$ & $\begin{array}{c}117.455 \\
(0.0000) \\
{[12]}\end{array}$ & $\begin{array}{l}124.334 \\
(0.0000) \\
{[12]}\end{array}$ & $\begin{array}{c}116.858 \\
(0.0000) \\
{[12]}\end{array}$ \\
\hline & USD & $\begin{array}{c}20.0181 \\
(0.4568) \\
{[12]}\end{array}$ & $\begin{array}{c}43.4665 \\
(0.0018) \\
{[12]}\end{array}$ & $\begin{array}{c}17.7005 \\
(0.6071) \\
{[12]}\end{array}$ & $\begin{array}{c}42.3566 \\
(0.0025) \\
{[12]}\end{array}$ & $\begin{array}{c}20.2847 \\
(0.4403) \\
{[12]}\end{array}$ & $\begin{array}{c}44.1448 \\
(0.0014) \\
{[12]}\end{array}$ \\
\hline
\end{tabular}

Source: Authors calculation 
Both Fisher ADF tests' statistics (Table 9 and Table 10) demonstrate similar results. There is again very strong evidence for PPP validity in case of EUR reference rates as the null is strongly rejected in all variations of the tests in estimating both test statistics. On the other hand, both Maddala and $\mathrm{Wu} \chi^{2}$ statistic and Choi $\mathrm{Z}$ statistic show evidence for PPP in USD rates in the post-crisis period when individual effects and individual linear trends are applied. However, the null is rejected for USD rates also by Choi Z statistic (Table 10) in the whole period when Schwarz information criteria is considered along with individual effects.

The PPP for EUR reference rates is also strongly supported by results of Fisher PP tests (Table 11 and Table 12) as the null of a unit root is decisively rejected in all combinations of tests' parameters for both test statistics and for all three periods under investigation. The Fisher PP tests provide some more support for PPP in case of USD reference rates. Maddala and $\mathrm{Wu} \chi^{2}$ statistics (Table 11) completely support the PPP for USD in the whole observed period and in the post-crises period. While Choi Z statistics (Table 12) show less strong support in the case of USD rate, since the null of a unit root is rejected in the whole period when individual effects are applied, and the post-crises period when individual effects and individual linear trends are included.

Table 10. Results of Fisher ADF tests (Choi Z statistic), deflator: CPI (Hotels and restaurants)

\begin{tabular}{|c|c|c|c|c|c|c|c|}
\hline \multirow{3}{*}{ 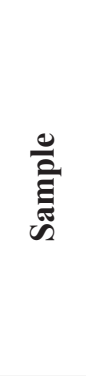 } & \multirow{3}{*}{ 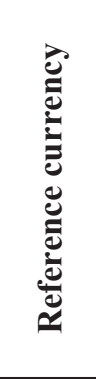 } & \multicolumn{2}{|c|}{$\begin{array}{c}\text { Schwarz information } \\
\text { criterion }\end{array}$} & \multicolumn{2}{|c|}{$\begin{array}{c}\text { Akaike information } \\
\text { criterion }\end{array}$} & \multicolumn{2}{|c|}{$\begin{array}{c}\text { Hannan-Quinn } \\
\text { information criterion }\end{array}$} \\
\hline & & $\begin{array}{c}\text { Individual } \\
\text { effects }\end{array}$ & $\begin{array}{c}\text { Individual } \\
\text { effects and } \\
\text { individual } \\
\text { linear trends }\end{array}$ & $\begin{array}{c}\text { Individual } \\
\text { effects }\end{array}$ & $\begin{array}{l}\text { Individual } \\
\text { effects and } \\
\text { individual } \\
\text { linear trends }\end{array}$ & $\begin{array}{c}\text { Individual } \\
\text { effects }\end{array}$ & $\begin{array}{l}\text { Individual } \\
\text { effects and } \\
\text { individual } \\
\text { linear trends }\end{array}$ \\
\hline & & $\begin{array}{c}\mathrm{Z} \\
\text { (p-value) } \\
\text { [no. of lags] }\end{array}$ & $\begin{array}{c}\mathrm{Z} \\
\text { (p-value) } \\
\text { [no. of lags] }\end{array}$ & $\begin{array}{c}\mathrm{Z} \\
\text { (p-value) } \\
\text { [no. of lags] }\end{array}$ & $\begin{array}{c}\mathrm{Z} \\
\text { (p-value) } \\
\text { [no. of lags] }\end{array}$ & $\begin{array}{c}\mathrm{Z} \\
\text { (p-value) } \\
\text { [no. of lags] }\end{array}$ & $\begin{array}{c}\mathrm{Z} \\
\text { (p-value) } \\
\text { [no. of lags] }\end{array}$ \\
\hline \multirow{2}{*}{ 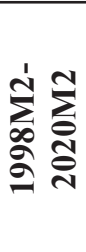 } & EUR & $\begin{array}{c}-7.65036 \\
(0.0000) \\
{[15]}\end{array}$ & $\begin{array}{c}-7.62678 \\
(0.0000) \\
{[15]}\end{array}$ & $\begin{array}{c}-7.10807 \\
(0.0000) \\
{[15]}\end{array}$ & $\begin{array}{c}-7.22082 \\
(0.0000) \\
{[15]}\end{array}$ & $\begin{array}{c}-7.73424 \\
(0.0000) \\
{[15]}\end{array}$ & $\begin{array}{c}-7.74131 \\
(0.0000) \\
{[15]}\end{array}$ \\
\hline & USD & $\begin{array}{c}-1.29961 \\
(0.0969) \\
{[12]}\end{array}$ & $\begin{array}{c}0.92966 \\
(0.8237) \\
{[12]}\end{array}$ & $\begin{array}{c}-0.63562 \\
(0.2625) \\
{[14]}\end{array}$ & $\begin{array}{c}1.70002 \\
(0.9554) \\
{[14]}\end{array}$ & $\begin{array}{c}-0.67625 \\
(0.2494) \\
{[14]}\end{array}$ & $\begin{array}{c}1.48968 \\
(0.9318) \\
{[13]}\end{array}$ \\
\hline \multirow{2}{*}{ 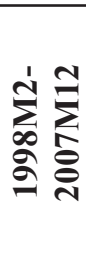 } & EUR & $\begin{array}{c}-6.67968 \\
(0.0000) \\
{[12]}\end{array}$ & $\begin{array}{c}-3.90957 \\
(0.0000) \\
{[12]}\end{array}$ & $\begin{array}{c}-4.77008 \\
(0.0000) \\
{[12]} \\
\end{array}$ & $\begin{array}{c}-2.86049 \\
(0.0021) \\
{[12]}\end{array}$ & $\begin{array}{c}-6.63377 \\
(0.0000) \\
{[12]}\end{array}$ & $\begin{array}{c}-4.66610 \\
(0.0000) \\
{[12]} \\
\end{array}$ \\
\hline & USD & $\begin{array}{c}2.53905 \\
(0.8667) \\
{[12]}\end{array}$ & $\begin{array}{c}2.56702 \\
(0.9949) \\
{[12]}\end{array}$ & $\begin{array}{c}2.70782 \\
(0.9966) \\
{[12]}\end{array}$ & $\begin{array}{c}1.97028 \\
(0.9756) \\
{[12]}\end{array}$ & $\begin{array}{c}2.61035 \\
(0.9955) \\
{[12]}\end{array}$ & $\begin{array}{c}2.01479 \\
(0.9780) \\
{[12]}\end{array}$ \\
\hline \multirow{2}{*}{ 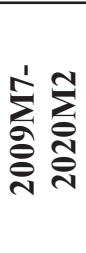 } & EUR & $\begin{array}{c}-5.30810 \\
(0.0000) \\
{[12]}\end{array}$ & $\begin{array}{c}-5.41091 \\
(0.0000) \\
{[12]}\end{array}$ & $\begin{array}{c}-5.02036 \\
(0.0000) \\
{[12]}\end{array}$ & $\begin{array}{c}-5.55301 \\
(0.0000) \\
{[12]}\end{array}$ & $\begin{array}{c}-5.40855 \\
(0.0000) \\
{[12]}\end{array}$ & $\begin{array}{c}5.50803 \\
(0.0000) \\
{[12]}\end{array}$ \\
\hline & USD & $\begin{array}{c}0.11435 \\
(0.5455) \\
{[12]}\end{array}$ & $\begin{array}{c}-3.69930 \\
(0.0001) \\
{[12]}\end{array}$ & $\begin{array}{c}0.52249 \\
(0.6993) \\
{[12]}\end{array}$ & $\begin{array}{c}-3.65597 \\
(0.0001) \\
{[12]}\end{array}$ & $\begin{array}{c}0.07450 \\
(0.5297) \\
{[12]}\end{array}$ & $\begin{array}{c}-3.75275 \\
(0.0001) \\
{[12]}\end{array}$ \\
\hline
\end{tabular}

Source: Authors calculation

The two empirical approaches, which consider common unit root processes (Levin, Lin and Chu test, and Breitung test), provide less evidence for PPP when based on price indices of hotels and restaurants. According to the results of Levin, Lin and Chu test in Table 13, there is evidence in favour of PPP for EUR reference rates in the whole period in all variations of the test, except for the case when Barlett kernel with individual effects and individual linear trend are applied. 
The EUR reference rates follow the features of PPP concept also in the pre-crisis period for all three kernel options when individual effects are incorporated. While in the post-crisis period the null of unit root can be rejected for EUR reference rates only in one version of Levin, Lin in Chu test taking into account quadratic spectral kernel with individual effects and individual linear trend. For USD reference rates the null hypothesis of a unit root is rejected for the whole observed period when individual effects are taken into account. There is no evidence in favour of PPP in USD reference rates in the pre-crisis and post-crisis period.

Table 11. Results of Fisher PP tests (Maddala and $\mathrm{Wu} \chi^{2}$ statistic), deflator: CPI

(Hotels and restaurants)

\begin{tabular}{|c|c|c|c|c|c|c|c|}
\hline \multirow{3}{*}{ 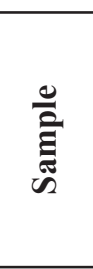 } & \multirow{3}{*}{ 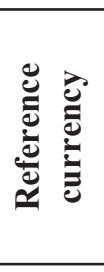 } & \multicolumn{2}{|c|}{ Bartlett kernel } & \multicolumn{2}{|c|}{ Parzen kernel } & \multicolumn{2}{|c|}{ Quadratic spectral kernel } \\
\hline & & $\begin{array}{l}\text { Individual } \\
\text { effects }\end{array}$ & $\begin{array}{l}\text { Individual } \\
\text { effects and } \\
\text { individual } \\
\text { linear trends }\end{array}$ & $\begin{array}{l}\text { Individual } \\
\text { effects }\end{array}$ & $\begin{array}{l}\text { Individual } \\
\text { effects and } \\
\text { individual } \\
\text { linear trends }\end{array}$ & $\begin{array}{l}\text { Individual } \\
\text { effects }\end{array}$ & $\begin{array}{l}\text { Individual } \\
\text { effects and } \\
\text { individual } \\
\text { linear trends }\end{array}$ \\
\hline & & $\chi^{2}$ (p-value) & $\chi^{2}$ (p-value) & $\chi^{2}$ (p-value) & $\chi^{2}$ (p-value) & $\chi^{2}$ (p-value) & $\chi^{2}$ (p-value) \\
\hline \multirow{2}{*}{ 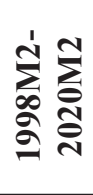 } & EUR & $\begin{array}{l}666.525 \\
(0.0000)\end{array}$ & $\begin{array}{c}676.753 \\
(0.0000)\end{array}$ & $\begin{array}{l}644.855 \\
(0.0000)\end{array}$ & $\begin{array}{l}642.268 \\
(0.0000)\end{array}$ & $\begin{array}{c}634.878 \\
(0.0000)\end{array}$ & $\begin{array}{l}630.893 \\
(0.0000)\end{array}$ \\
\hline & USD & $\begin{array}{l}41.6876 \\
(0.0030) \\
\end{array}$ & $\begin{array}{l}32.9949 \\
(0.0338)\end{array}$ & $\begin{array}{l}44.6124 \\
(0.0012)\end{array}$ & $\begin{array}{l}36.3537 \\
(0.0140) \\
\end{array}$ & $\begin{array}{l}41.7713 \\
(0.0030) \\
\end{array}$ & $\begin{array}{l}33.3856 \\
(0.0306)\end{array}$ \\
\hline \multirow{2}{*}{ 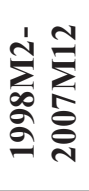 } & EUR & $\begin{array}{l}403.790 \\
(0.0000)\end{array}$ & $\begin{array}{l}373.877 \\
(0.0000)\end{array}$ & $\begin{array}{l}410.077 \\
(0.0000)\end{array}$ & $\begin{array}{l}378.845 \\
(0.0000)\end{array}$ & $\begin{array}{l}407.104 \\
(0.0000)\end{array}$ & $\begin{array}{l}376.335 \\
(0.0000)\end{array}$ \\
\hline & USD & $\begin{array}{l}25.8521 \\
(0.1708)\end{array}$ & $\begin{array}{l}27.5348 \\
(0.1209)\end{array}$ & $\begin{array}{l}27.1071 \\
(0.1323)\end{array}$ & $\begin{array}{l}30.4934 \\
(0.0622)\end{array}$ & $\begin{array}{l}24.9912 \\
(0.2018)\end{array}$ & $\begin{array}{l}27.4475 \\
(0.1231)\end{array}$ \\
\hline \multirow{2}{*}{ 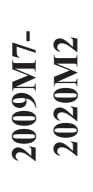 } & EUR & $\begin{array}{l}385.018 \\
(0.0000)\end{array}$ & $\begin{array}{l}372.312 \\
(0.0000)\end{array}$ & $\begin{array}{l}374.269 \\
(0.0000)\end{array}$ & $\begin{array}{l}355.989 \\
(0.0000)\end{array}$ & $\begin{array}{l}398.696 \\
(0.0000)\end{array}$ & $\begin{array}{l}378.941 \\
(0.0000)\end{array}$ \\
\hline & USD & $\begin{array}{l}39.9205 \\
(0.0051)\end{array}$ & $\begin{array}{l}76.4172 \\
(0.0000)\end{array}$ & $\begin{array}{l}41.6533 \\
(0.0031)\end{array}$ & $\begin{array}{l}79.2599 \\
(0.0000)\end{array}$ & $\begin{array}{l}40.1241 \\
(0.0048)\end{array}$ & $\begin{array}{l}77.8274 \\
(0.0000)\end{array}$ \\
\hline
\end{tabular}

Source: Authors calculation

Table 12. Results of Fisher PP tests (Choi Z statistic), deflator: CPI (Hotels and restaurants)

\begin{tabular}{|c|c|c|c|c|c|c|c|}
\hline \multirow{3}{*}{$\underset{\bar{E}}{\stackrel{0}{E}}$} & \multirow{3}{*}{ 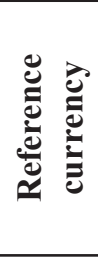 } & \multicolumn{2}{|c|}{ Bartlett kernel } & \multicolumn{2}{|c|}{ Parzen kernel } & \multicolumn{2}{|c|}{ Quadratic spectral kernel } \\
\hline & & $\begin{array}{l}\text { Individual } \\
\text { effects }\end{array}$ & $\begin{array}{c}\text { Individual } \\
\text { effects and } \\
\text { individual } \\
\text { linear trends } \\
\end{array}$ & $\begin{array}{l}\text { Individual } \\
\text { effects }\end{array}$ & \begin{tabular}{|c|} 
Individual \\
effects and \\
individual \\
linear trends \\
\end{tabular} & $\begin{array}{c}\text { Individual } \\
\text { effects }\end{array}$ & $\begin{array}{c}\text { Individual } \\
\text { effects and } \\
\text { individual } \\
\text { linear trends }\end{array}$ \\
\hline & & $\mathrm{Z}$ (p-value) & $\mathrm{Z}$ (p-value) & $\mathrm{Z}$ (p-value) & $\mathrm{Z}$ (p-value) & $\mathrm{Z}$ (p-value) & $\mathrm{Z}$ (p-value) \\
\hline \multirow{2}{*}{ 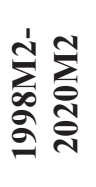 } & EUR & $\begin{array}{l}-21.7726 \\
(0.0000)\end{array}$ & $\begin{array}{l}-20.8641 \\
(0.0000)\end{array}$ & $\begin{array}{l}-21.5662 \\
(0.0000)\end{array}$ & $\begin{array}{l}-20.3436 \\
(0.0000)\end{array}$ & $\begin{array}{l}-21.4848 \\
(0.0000)\end{array}$ & $\begin{array}{l}-20.2027 \\
(0.0000)\end{array}$ \\
\hline & USD & $\begin{array}{l}-2.77483 \\
(0.0028)\end{array}$ & $\begin{array}{l}-0.74237 \\
(0.2289)\end{array}$ & $\begin{array}{l}-2.85483 \\
(0.0022)\end{array}$ & $\begin{array}{r}-0.83635 \\
(0.2015)\end{array}$ & $\begin{array}{l}-2.73610 \\
(0.0031)\end{array}$ & $\begin{array}{r}-0.70666 \\
(0.2399)\end{array}$ \\
\hline \multirow{2}{*}{ 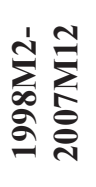 } & EUR & $\begin{array}{l}-16.2529 \\
(0.0000)\end{array}$ & $\begin{array}{l}-13.8444 \\
(0.0000)\end{array}$ & $\begin{array}{l}-16.4123 \\
(0.0000)\end{array}$ & $\begin{array}{l}-13.9742 \\
(0.0000)\end{array}$ & $\begin{array}{r}-16.3664 \\
(0.0000)\end{array}$ & $\begin{array}{l}-13.8719 \\
(0.0000)\end{array}$ \\
\hline & USD & $\begin{array}{l}0.93625 \\
(0.1708)\end{array}$ & $\begin{array}{l}1.08963 \\
(0.8621)\end{array}$ & $\begin{array}{l}1.00182 \\
(0.8418)\end{array}$ & $\begin{array}{c}1.12629 \\
(0.8700)\end{array}$ & $\begin{array}{c}1.23052 \\
(0.8907)\end{array}$ & $\begin{array}{c}1.33332 \\
(0.9088)\end{array}$ \\
\hline \multirow{2}{*}{ 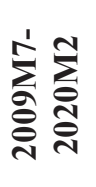 } & EUR & $\begin{array}{l}-14.8505 \\
(0.0000)\end{array}$ & $\begin{array}{l}-16.0288 \\
(0.0000)\end{array}$ & $\begin{array}{l}-14.3970 \\
(0.0000)\end{array}$ & $\begin{array}{l}-15.4381 \\
(0.0000)\end{array}$ & $\begin{array}{l}-15.1032 \\
(0.0000)\end{array}$ & $\begin{array}{l}-16.1669 \\
(0.0000)\end{array}$ \\
\hline & USD & $\begin{array}{l}-1.33929 \\
(0.0902)\end{array}$ & $\begin{array}{l}-5.73997 \\
(0.0000)\end{array}$ & $\begin{array}{l}-1.33952 \\
(0.0902)\end{array}$ & $\begin{array}{l}-5.89413 \\
(0.0000)\end{array}$ & $\begin{array}{l}-1.31725 \\
(0.0939)\end{array}$ & $\begin{array}{l}-5.87424 \\
(0.0000)\end{array}$ \\
\hline
\end{tabular}

Source: Authors calculation 
Table 13. Results of Levin, Lin and Chu test, deflator: CPI (Hotels and restaurants)

\begin{tabular}{|c|c|c|c|c|c|c|c|}
\hline \multirow{3}{*}{ 伺 } & \multirow{3}{*}{ 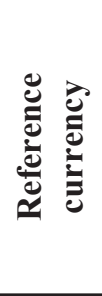 } & \multicolumn{2}{|c|}{ Bartlett kernel } & \multicolumn{2}{|c|}{ Parzen kernel } & \multicolumn{2}{|c|}{ Quadratic spectral kernel } \\
\hline & & $\begin{array}{l}\text { Individual } \\
\text { effects }\end{array}$ & $\begin{array}{c}\text { Individual } \\
\text { effects and } \\
\text { individual } \\
\text { linear trends }\end{array}$ & $\begin{array}{c}\text { Individual } \\
\text { effects }\end{array}$ & \begin{tabular}{|c|} 
Individual \\
effects and \\
individual \\
linear trends
\end{tabular} & $\begin{array}{l}\text { Individual } \\
\text { effects }\end{array}$ & $\begin{array}{l}\text { Individual } \\
\text { effects and } \\
\text { individual } \\
\text { linear trends }\end{array}$ \\
\hline & & $\begin{array}{l}t^{*} \text { (p-value) } \\
\text { [no. of lags] }\end{array}$ & $\begin{array}{l}* \text { (p-value) } \\
{[\text { no. of lags] }}\end{array}$ & $\begin{array}{l}* \text { (p-value) } \\
\text { [no. of lags] }\end{array}$ & $\begin{array}{l}* \text { (p-value) } \\
{[\text { no. of lags] }}\end{array}$ & $\begin{array}{l}t^{*} \text { (p-value) } \\
\text { [no. of lags] }\end{array}$ & $\begin{array}{l}t^{*} \text { (p-value) } \\
\text { [no. of lags] }\end{array}$ \\
\hline \multirow{2}{*}{ 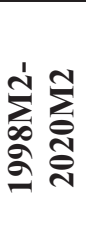 } & EUR & $\begin{array}{c}-1.88932 \\
(0.0294) \\
{[15]}\end{array}$ & $\begin{array}{c}-0.32141 \\
(0.3740) \\
{[15]}\end{array}$ & $\begin{array}{c}-3.40011 \\
(0.0003) \\
{[15]}\end{array}$ & $\begin{array}{c}-3.95826 \\
(0.0000) \\
{[15]}\end{array}$ & $\begin{array}{c}-3.51581 \\
(0.0002) \\
{[15]}\end{array}$ & $\begin{array}{c}-4.39519 \\
(0.0000) \\
{[15]}\end{array}$ \\
\hline & USD & $\begin{array}{c}-1.39489 \\
(0.0815) \\
{[12]}\end{array}$ & $\begin{array}{c}0.34137 \\
(0.6373) \\
{[12]}\end{array}$ & $\begin{array}{c}-1.69979 \\
(0.0446) \\
{[12]}\end{array}$ & $\begin{array}{c}-0.31363 \\
(0.3769) \\
{[12]}\end{array}$ & $\begin{array}{c}-1.64118 \\
(0.0504) \\
{[12]}\end{array}$ & $\begin{array}{c}-0.18610 \\
(0.4262) \\
{[12]}\end{array}$ \\
\hline \multirow{2}{*}{ 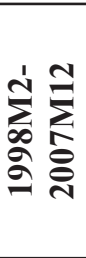 } & EUR & $\begin{array}{c}-2.76193 \\
(0.0029) \\
{[12]} \\
\end{array}$ & $\begin{array}{c}2.052020 \\
(0.9799) \\
{[12]} \\
\end{array}$ & $\begin{array}{c}-3.75630 \\
(0.0001) \\
{[12]} \\
\end{array}$ & $\begin{array}{c}-0.26404 \\
(0.3959) \\
{[12]} \\
\end{array}$ & $\begin{array}{c}-3.80866 \\
(0.0001) \\
{[12]} \\
\end{array}$ & $\begin{array}{c}0.23213 \\
(0.4082) \\
{[12]}\end{array}$ \\
\hline & USD & $\begin{array}{c}-0.03910 \\
(0.4844) \\
{[12]}\end{array}$ & $\begin{array}{c}0.27916 \\
(0.6099) \\
{[12]}\end{array}$ & $\begin{array}{c}-0.26202 \\
(0.3967) \\
{[12]}\end{array}$ & $\begin{array}{c}-0.44273 \\
(0.3290) \\
{[12]}\end{array}$ & $\begin{array}{c}-0.36061 \\
(0.3592) \\
{[12]}\end{array}$ & $\begin{array}{c}-0.47432 \\
(0.3176) \\
{[12]}\end{array}$ \\
\hline \multirow{2}{*}{ 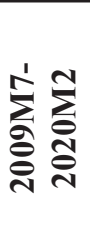 } & EUR & $\begin{array}{c}4.27647 \\
(1.0000) \\
{[12]}\end{array}$ & $\begin{array}{c}9.20204 \\
(1.0000) \\
{[12]}\end{array}$ & $\begin{array}{c}1.40161 \\
(0.9195) \\
{[12]}\end{array}$ & $\begin{array}{c}-0.73209 \\
(0.2321) \\
{[12]}\end{array}$ & $\begin{array}{c}0.99556 . \\
(0.8403) \\
{[12]}\end{array}$ & $\begin{array}{c}-2.10542 \\
(0.0176) \\
{[12]}\end{array}$ \\
\hline & USD & $\begin{array}{c}1.8852 \\
(0.9712) \\
{[12]}\end{array}$ & $\begin{array}{c}0.72106 \\
(0.7646) \\
{[12]}\end{array}$ & $\begin{array}{c}1.47561 \\
(0.9300) \\
{[12]}\end{array}$ & $\begin{array}{c}-0.62936 \\
(0.2646) \\
{[12]}\end{array}$ & $\begin{array}{c}1.60785 \\
(0.9461) \\
{[12]}\end{array}$ & $\begin{array}{c}-0.17478 \\
(0.4306) \\
{[12]}\end{array}$ \\
\hline
\end{tabular}

Notes: The number of lags used in each cross-section ADF regression $\left(\mathrm{p}_{\mathrm{i}}\right)$ was defined by the Schwarz information criterion. Computation was conducted with Newey-West bandwidth selection.

Source: Authors calculation

Table 14. Results of Breitung test, deflator: CPI (Hotels and restaurants)

\begin{tabular}{|c|c|c|c|c|}
\hline \multirow{3}{*}{ 产 } & \multirow{3}{*}{ 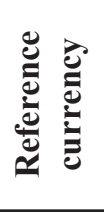 } & $\begin{array}{c}\text { Schwarz information } \\
\text { criterion }\end{array}$ & $\begin{array}{c}\text { Akaike information } \\
\text { criterion }\end{array}$ & $\begin{array}{c}\text { Hannan-Quinn } \\
\text { information criterion }\end{array}$ \\
\hline & & $\begin{array}{l}\text { Individual effects and } \\
\text { individual linear trends }\end{array}$ & $\begin{array}{l}\text { Individual effects and } \\
\text { individual linear trends }\end{array}$ & $\begin{array}{l}\text { Individual effects and } \\
\text { individual linear trends }\end{array}$ \\
\hline & & t-stat (p-value) [no. of lags] & t-stat (p-value) [no. of lags] & t-stat (p-value) [no. of lags] \\
\hline \multirow{2}{*}{ 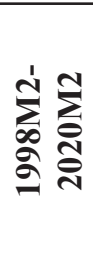 } & EUR & $\begin{array}{c}0.86251 \\
(0.8054) \\
{[15]}\end{array}$ & $\begin{array}{c}0.60588 \\
(0.7277) \\
{[15]}\end{array}$ & $\begin{array}{c}0.61908 \\
(0.7321) \\
{[15]}\end{array}$ \\
\hline & USD & $\begin{array}{c}-1.73196 \\
(0.0416) \\
{[12]} \\
\end{array}$ & $\begin{array}{c}-1.34780 \\
(0.0889) \\
{[14]} \\
\end{array}$ & $\begin{array}{c}-1.45936 \\
(0.0722) \\
{[13]} \\
\end{array}$ \\
\hline \multirow{2}{*}{ 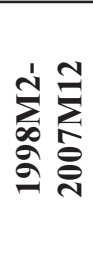 } & EUR & $\begin{array}{c}-3.24075 \\
(0.0006) \\
{[12]}\end{array}$ & $\begin{array}{c}-3.15809 \\
(0.0008) \\
{[12]}\end{array}$ & $\begin{array}{c}-3.30601 \\
(0.0005) \\
{[12]} \\
\end{array}$ \\
\hline & USD & $\begin{array}{c}2.72714 \\
(0.9968) \\
{[12]} \\
\end{array}$ & $\begin{array}{c}2.92384 \\
(0.9983) \\
{[12]} \\
\end{array}$ & $\begin{array}{c}2.73973 \\
(0.9969) \\
{[12]} \\
\end{array}$ \\
\hline \multirow{2}{*}{ 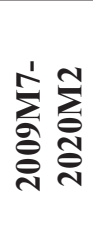 } & EUR & $\begin{array}{c}-0.08960 \\
(0.4643) \\
{[12]} \\
\end{array}$ & $\begin{array}{c}0.23644 \\
(0.5935) \\
{[12]} \\
\end{array}$ & $\begin{array}{c}-0.45412 \\
(0.3249) \\
{[12]} \\
\end{array}$ \\
\hline & USD & $\begin{array}{c}-3.39440 \\
(0.0003) \\
{[12]}\end{array}$ & $\begin{array}{c}-3.65332 \\
(0.0001) \\
{[12]}\end{array}$ & $\begin{array}{c}-3.14114 \\
(0.0008) \\
{[12]}\end{array}$ \\
\hline
\end{tabular}

Source: Authors calculation 
Table 14 displays results of Breitung test when CPI for hotels and restaurants is used in the calculation of real exchange rates. For EUR reference rates the null hypothesis is strongly rejected in the pre-crisis period for all three alterations of the test. For USD reference rates there is indication for PPP validity in the whole period and the post-crisis period, in both cases for all three variations of the Breitung test.

\section{FUTURE RESEARCH DIRECTIONS}

The results discussed indicate several alternatives for our future research. Operating with real effective exchange rates instead of bilateral real exchange rates is the first step in extending our present knowledge about the PPP in the Mediterranean countries. Experimenting with different tradable and non-tradable price indices could further enrich the PPP discourse. New insights into the robustness of the mean reversion process can be also gained by implementing second-generation panel unit root tests, as well as taking into account possible nonlinearities in exchange rates.

\section{CONCLUSION}

This study provides a detailed analysis of the validity of PPP for a cluster of 15 Mediterranean countries. Besides using the conventional price level indicators to pinpoint the presence of equilibrium exchange rate parity, we further deepen our analysis as we search for the PPP by scrutinizing tourism price indices of the observed countries. In order to inspect the mean reversion of real exchange rates by relying on the dynamics of price levels in the tourism sector, we employ a wide range of different panel unit root tests, present estimates for euro rates and for US dollar rates simultaneously, and consider the importance of the PPP concept in subperiods, taking into account the possible structural shifts caused by the Great Recession.

Many important findings can be highlighted from the research. First, after evaluating the matrix of all the generated empirical outcomes from applying various consumer price indicators, numeraire currencies and panel stationary tests ( 84 outcomes in total), the hypothesis about the unit root process can be rejected in 58\% of the cases. Furthermore, support for the PPP is documented in $67 \%$ of all the cases when the results are based on the consumer price indices for hotels and restaurants. Second, for the whole period, the results are in favour of PPP in $71 \%$ of the cases with tourism price indices and half of the cases when general consumer price indices are used. Third, irrespective of the chosen type of price indices, there is significantly more evidence for the PPP relation in the post-Great Recession period compared to the period 1998-2007. Consequently, in the post-crisis period, in 79\% of cases analysed, the countries' real exchange rates have stationary properties. Fourth, with the sole exception of the Breitung test, all the panel unit root tests reject the null hypothesis on the non-stationarity of real exchange rates concerning EUR rates from 1998 to 2020. Similar results are discovered for the post-Great Recession period. Fifth, in case of US dollar-based real exchange rates the PPP theory holds for the post-crisis period, significantly weaker is the empirical evidence for the entire period from 1998 to 2020, whereas for subperiod 1998-2007 the hypothesis of non-stationarity of real exchange rates according to the US dollar could not be rejected with any of stationarity tests used in this study. The evidence of mean reversion is stronger for bilateral real exchange rates concerning the euro, especially under price indices for hotels and restaurants.

Eleftheriou and Müller-Platenberg (2018) argue that prices of traded and nontraded goods only marginally contribute to real exchange rate dynamics. Instead, movements in currency mar- 
kets owing to the balance of payments flows and changes in real interest rates are the primary component in the fluctuation of real exchange rates. Insufficient flexibility of relative prices to induce adjustment of real exchange rate toward its constant equilibrium under the euro regime can also cause deviations from parity conditions (Huang \& Yang, 2015). According to Bénassy-Quéré and Coulibaly (2014), the key forces behind the documented lack of price convergence and departures from PPP in euro area countries (Bergin \& Glick, 2007; Berka \& Devereux, 2013) are various product market regulations in non-tradable production and employment protection measures among these economies.

Despite numerous market imperfections which can cause long-run deviations from PPP levels, the presented results in our study deliver strong evidence in favour of this exchange rate theory. The evidence of mean reversion of real exchange rates in the group of Mediterranean countries is stronger (1) with price indices for hotels and restaurants, (2) in cases when the calculations are performed for EUR rates, and (3) for the post-Great Recession period. The growing tradability of services (Rabe \& Waddle, 2020) and the prominent role of tourism in impacting international prices and income disparities among countries and geographical regions (Tubadji \& Nijkamp, 2018) are in accord with the empirical outcomes in this study. Because under PPP the price competition in tourism services is an economic integrator of Mediterranean countries, the tourism sector acts as an important arbitrage element in international trade of services, goods and movements of people.

\section{REFERENCES}

Arize, A. C., Malindretos, J., \& Ghosh, D. (2015). Purchasing power parity-symmetry and proportionality: evidence from 116 countries. International Review of Economics and Finance, 37(May), 69-85. https://doi.org/10.1016/j.iref.2014.11.014

Bahmani-Oskooee, M., Chang, T., \& Liu, W. C. (2014). Revisiting purchasing power parity in 34 OECD countries: sequential panel selection method. Applied Economics Letters, 21(18), 12831287. https://doi.org/10.1080/13504851.2014.923553

Bahmani-Oskooee, M., \& Hegerty, S. W. (2010). Bounds testing cointegration methods and PPP: evidence from 123 countries. Applied Economics Letters, 17(14), 1335-1340. https://doi. org $/ 10.1080 / 13504850902967456$

Bahmani-Oskooee,M,\&Kandil,M.(2007). Real andnominal effectiveexchangeratesinMENAcountries: 1970-2004. Applied Economics, 39(19), 2489-2501. https://doi.org/10.1080/00036840600690306

Bekö, J., \& Boršič, D. (2018). Testing the purchasing power parity hypothesis: case of ASEAN economies. Naše Gospodarstvo/Our Economy, 64(4), 74-85. https://doi.org/10.2478/ngoe-2018-0024

Bekő, J., Kavkler, A., \& Boršič, D. (2012). PPP and nonlinearity of real exchange rates: new evidence from transition economies. Applied Economics Letters, 19(18), 1851-1855. https://doi.org/10.1080 $/ 13504851.2012 .667544$

Bergin, P. R., \& Glick, R. (2007). Tradability, productivity, and international economic integration. Journal of International Economics, 73(1), 128-151. https://doi.org/10.1016/j.jinteco.2007.01.002

Berka, M., \& Devereux, M. B. (2013). Trends in European real exchange rates. Economic Policy, 28(74), 193-242. https://doi.org/10.1111/1468-0327.12006

Bénassy-Quéré, A., \& Coulibaly, D. (2014). The impact of market regulations on intra-European real exchange rates. Review of World Economics, 150(3), 529-556. https://doi.org/10.1007/s10290-0140185-6

Boršič, D., Baharumshah, A. Z., \& Bekő, J. (2012). Are we getting closer to purchasing power parity in Central and Eastern European economies? Applied Economics Letters, 19(1), 87-91. https://doi.or $\mathrm{g} / 10.1080 / 13504851.2011 .568383$ 
Boršič, D., \& Bekő, J. (2018) Purchasing power parity in ASEAN+3: an application of panel unit root tests. Croatian Review of Economic, Business and Social Statistics, 4(1), 42-52. https://doi. org/10.2478/crebss-2018-0004

Breitung, J. (2000). The local power of some unit root tests for panel data. In B. Baltagi (Ed.), Advances in Econometrics, Vol. 15: Nonstationary Panels, Panel Cointegration, and Dynamic Panels (pp. 161-178), Amsterdam: JAI Press. https://doi.org/10.1016/S0731-9053(00)15006-6

Camarero, M., Cuestas, J. C., \& Ordóñez, J. (2006). Purchasing power parity versus the EU in the Mediterranean countries. Applied Financial Economics, 16(1-2), 157-167. https://doi. org/10.1080/09603100500390620

Choi, I. (2001). Unit root tests for panel data. Journal for International Money and Finance, 20(2), 249272. https://doi.org/10.1016/S0261-5606(00)00048-6

Christidou, M., \& Panagiotidis, T. (2010). Purchasing power parity and the European single currency: some new evidence. Economic Modelling, 27(5), 1116-1123. https://doi.org/10.1016/j.econmod.2010.03.008

Eleftheriou, M., \& Müller-Platenberg, N. A. (2018). The purchasing power parity fallacy: time to reconsider the PPP hypothesis. Open Economies Review, 29(3), 481-515. https://doi.org/10.1007/s11079017-9473-9

Emirmahmutoglu, F., \& Omay, T. (2014). Reexamining of PPP hypothesis: a nonlinear asymmetric heterogeneous panel unit root test. Economic Modelling, 40(June), 184-190. https://doi.org/10.1016/j. econmod.2014.03.028

Eurostat. (2020). Eurostat database. Available at: https://ec.europa.eu/eurostat/databrowser/view/PRC_ HICP_MMOR_custom_249560/default/table?lang=en [28 September 2020].

Froot, K. A., Kim, M, \& Rogoff, K. (2019). The law of one price over 700 years. Annals of Economics and Finance, 20(1), 1-35.

Froot, K. A., \& Rogoff, K. (1995). Perspectives on PPP and long-run real exchange rates. In G. Grossman \& K. Rogoff (Ed.), Handbook of International Economics Vol. III, (pp. 1647-1688). Elsevier Science. https://doi.org/10.1016/S1573-4404(05)80012-7

Giannellis, N., \& Papadopoulos, A. P. (2010). Nonlinear exchange rate adjustment in the enlarged Eurozone: evidence and implications for candidate countries. Review of International Economics, 18(4), 741-757. https://doi.org/10.1111/j.1467-9396.2010.00895.x

Huang, C. H., \& Yang, C. Y. (2015). European exchange rate regimes and purchasing power parity: an empirical study on eleven Eurozone countries. International Review of Economics and Finance, 35(January), 100-109. https://doi.org/10.1016/j.iref.2014.09.008

Hurlin, C. (2010). What would Nelson and Plosser find had they used panel unit root tests? Applied Economics, 42(12), 1515-1531. https://doi.org/10.1080/00036840701721539

Im, K. S., Pesaran, M. H., \& Shin, Y. (2003). Testing for unit roots in heterogeneous panels. Journal of Econometrics, 115(1), 53-74. https://doi.org/10.1016/S0304-4076(03)00092-7

International Monetary Fund. (2020). International financial statistics. Available at: https://data.imf. org/?sk=4c514d48-b6ba-49ed-8ab9-52b0cla0179b\&sId=1390030341854. [28 September 2020].

Knoema. (2020). Knoema database. Available at: https://knoema.com/atlas/topics/Tourism/Travel-and-Tourism-Total-Contribution-to-GDP/Contribution-of-travel-and-tourism-to-GDP-percentof-GDP. [20 November 2020].

Koedijk, K. G., Tims, B., \& van Dijk, M. A. (2004). Purchasing power parity and the euro area. Journal of International Money and Finance, 23(7-8), 1081-1107. https://doi.org/10.1016/j.jimonfin.2004.08.005

Koukouritakis, M. (2009). Testing the purchasing power parity: evidence from the new EU countries. Applied Economics Letters, 16(1), 39-44. https://doi.org/10.1080/13504850701735807 
Kula, F., Aslan, A., \& Feridun, M. (2011). Purchasing power parity in MENA revisited: empirical evidence in the presence of endogenously determined break points. Economic Research-Ekonomska istraživanja, 24(1), 1-12. https://doi.org/10.1080/1331677X.2011.11517441

Laureti, L. (2001). Purchasing power parity and integration - empirical evidence in the Mediterranean countries. Journal of Policy Modelling, 23(7), 731-751. https://doi.org/10.1016/S01618938(01)00074-6

Levin, A., Lin, C. F., \& Chu, C. (2002). Unit root testing in panel data: asymptotic and finite-sample properties. Journal of Econometrics, 108(1), 1-24. https://doi.org/10.1016/S0304-4076(01)00098-7

Lopez, C., \& Papell, D. H. (2007). Convergence to purchasing power parity at the commencement of the euro. Review of International Economics, 15(1), 1-16. https://doi.org/10.1111/j.14679396.2007.00631.x

Maddala, G. S., \& Wu, S. (1999). A comparative study of unit root tests with panel and a new simple test. Oxford Bulletin of Economics and Statistics, 61(0), 631-653. https://doi.org/10.1111/14680084.0610s1631

NBER. (2012). US business cycle expansions and contractions. Available at: http://www.nber.org/cycles/US_Business_Cycle_Expansions_and_Contractions_20120423.pdf. [05 March 2018].

OECD. (2020). Consumer price indices (CPIs) - complete database. Available at: https://stats.oecd.org/ Index.aspx?DataSetCode=PRICES_CPI. [28 September 2020].

Papell, D. H., \& Prodan, R. (2020). Long-run purchasing power parity redux. Journal of International Money and Finance, 109(December), 1-12. https://doi.org/10.1016/j.jimonfin.2020.102260

Parikh, A., \& Wakerly, E. (2000). Real exchange rates and unit root tests. Weltwirtschaftliches Archiv, 136(3), 478-490. https://doi.org/10.1007/BF02707290

Rabe, C., \& Waddle, A. (2020). The evolution of purchasing power parity. Journal of International Money and Finance, 109(December), 1-21. https://doi.org/10.1016/j.jimonfin.2020.102237

Ramajo, J., \& Ferré, M. (2010). Purchasing power parity revisited: evidence from old and new tests for an organisation for economic co-operation and development panel. Applied Economics, 42(17), 2243-2260. https://doi.org/10.1080/00036840701765486

Su, J. J., Cheung, A., \& Roca, E. (2014). Does purchasing power parity hold? New evidence from wild-bootstrapped nonlinear unit root tests in the presence of heteroscedasticity. Economic Modelling, 36(January), 161-171. https://doi.org/10.1016/j.econmod.2013.09.029

Taylor, M. P. (2006). Real exchange rates and purchasing power parity: mean-reversion in economic thought. Applied Financial Economics, 16(1-2), 1-17. https://doi.org/10.1080/09603100500390067

Taylor, A. M., \& Taylor, M. P. (2004). The purchasing power parity debate. The Journal of Economic Perspectives, 18(4), 135-158. https://doi.org/10.1257/0895330042632744

The World Bank. (2020). The World Bank database. Available at: https://data.worldbank.org/indicator/ NE.TRD.GNFS.ZS. [20 November 2020].

Tubadji, A., \& Nijkamp, P. (2018). Revisiting the Balassa-Samuelson effect: international tourism and cultural proximity. Tourism Economics, 24(8), 915-944. https://doi.org/10.1177/1354816618781468

U.S. Bureau of Labor Statistics. (2020). Consumer price index (CPI) databases. Available at: https:// www.bls.gov/cpi/data.htm. [29 October 2020].

Wu, Y., \& Lin, E. S. (2011). Does purchasing power parity hold following the launch of the euro? Evidence from the panel unit root test. Applied Economics Letters, 18(2) 167-172. https://doi. org/10.1080/13504850903442970

Zhou, S., \& Kutan, A. M. (2011). Is the evidence for PPP reliable? A sustainability examination of the stationarity of real exchange rates. Journal of Banking \& Finance, 35(9), 2479-2490. https://doi. org/10.1016/j.jbankfin.2011.02.006 